\title{
Noradrenergic Neurons in the Locus Coeruleus of Birds Express TrkA, Transport NGF, and Respond to NGF
}

\author{
Christopher S. von Bartheld, ${ }^{1}$ Andreas Schober, ${ }^{1, a}$ Yoshito Kinoshita, ${ }^{1}$ Reg Williams,, ${ }^{2, b}$ Ted Ebendal, ${ }^{2}$ and \\ Mark Bothwell \\ 'Department of Physiology and Biophysics, University of Washington, Seattle, Washington 98195 and ${ }^{2}$ Department \\ of Developmental Biology, Biomedical Center, Uppsala University, Uppsala, Sweden
}

The chicken locus coeruleus contains a population of noradrenergic neurons which express the neurotrophin receptor p75 (von Bartheld and Bothwell, 1992). To determine which neurotrophin may regulate the development of noradrenergic neurons in the chicken locus coeruleus, expression of trk receptors, retrograde transport of neurotrophins, and responses to NGF were examined.

P75-expressing noradrenergic neurons were found to project to the basal forebrain. They transport radio-iodinated NGF after injections into this target. The retrograde transport of NGF is specific to the noradrenergic neuronal population as evidenced by double labeling with antibodies against dopamine- $\beta$-hydroxylase. The same neuronal population expresses trkA receptor mRNA. The size of noradrenergic neurons in the locus coeruleus proper, but not in the nucleus subcoeruleus, Is signiflcantly Increased after injections of NGF into the telencephalon, consistent with the hypothesis that target-derived NGF provides trophic support. Noradrenergic coeruleus neurons are rescued from toxic effects of 6-hydroxydopamine injected into the telencephalon when NGF is injected into the midbrain. NGF has no rescue effect when it is coinjected with 6-hydroxydopamine into the telencephalon. In explant or dissociated cultures, noradrenergic coeruleus neurons do not respond to elevated levels of NGF with increased neurite outgrowth. Taken together, these results suggest that NGF plays a role in the development and maintenance of noradrenergic coeruleus neurons in the chick brain. The data also support our previous conclusion that major species differences exist between birds (chicken) and mammals with regard to

\footnotetext{
Received July 1, 1994; revised Sept. 21, 1994; accepted Sept. 27, 1994.

We thank Dr. H. Tanaka (Kumamoto University, Japan) for the gift of p75 antibody and Dr. Ron Lindsay (Regeneron) for the gift of BDNF and NT-3. We also thank Dr. Ed Rubel (University of Washington) for generous permission to use microscopic equipment. Mr. Anders Bäckström kindly shared sequence information, and Dr. David Holtzman kindly shared data prior to publication. We thank Dr. Anton Reiner for critical comments on the manuscript. This study was supported by NIH Grants HD 29177 (C.S.v.B.) and NS 30305 (M.B.), German Science Foundation Grant 489/1-1 (A.S.), the Medical Faculty of Uppsala University (R.W.), and the Swedish Natural Science Research Council (B-BU 04024-313) (T.E.)

Correspondence should be addressed to Christopher S. von Bartheld, Department of Physiology and Biophysics SJ-40, University of Washington, Seattle, WA 98195 .

${ }^{2}$ Present address: Department of Anatomy and Cell Biology, University of Heidelberg, Germany.

${ }^{b}$ Present address: Department of Molecular Biology, Karolinska Institute, CMB Stockholm, Sweden.

Copyright (C) 1995 Society for Neuroscience $0270-6474 / 95 / 152225-15 \$ 05.00 / 0$
}

trophic regulation of presumptive homologous neuronal populations.

[Key words: locus coeruleus, noradrenaline, NGF, trkA, NGF receptor, Dil, chick embryo, retrograde transport, neu-

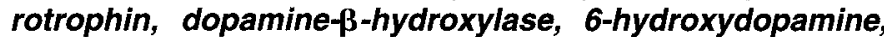
neuroprotection, in situ hybridization]

Several types of neurons have been characterized on the basis of morphological and functional criteria. Neurons of the "reticular type" are believed to serve integrative functions in the brain (Ramon-Moliner and Nauta, 1966; Hobson and Brazier, 1980; Mesulam et al., 1989) and are known for their remarkable regenerative capacities (Björklund et al., 1975). Prototypical neurons of the reticular type are those of the locus coeruleus. The noradrenergic coeruleus projections to the forebrain have been implicated in memory processing (Kety, 1970; Stephenson, 1991), and particularly in attentional aspects of learning (Mason, 1984). Neuronal populations of the reticular type maintain high levels of the neurotrophin receptor $\mathrm{p} 75$ in the mature brain, for example, the cholinergic neurons of the basal forebrain (Hefti, 1986; Thoenen et al., 1987; Olson, 1993) and the locus coeruleus (von Bartheld et al., 1991a; von Bartheld and Bothwell, 1992). These data suggest the possibility that neurotrophic factors released by the targets elicit sprouting and plasticity of locus coeruleus neurons. Trophic factors thus may be involved in mechanisms underlying integrative functions, including synaptic plasticity and processes related to memory (Purves, 1988; Thoenen, 1991).

Recently, we have shown that noradrenergic neurons in the locus coeruleus of the posthatch chicken maintain high levels of mRNA for the neurotrophin receptor p75 (von Bartheld and Bothwell, 1992). Most actions of the neurotrophins are mediated by a different class of receptors, tyrosine kinase receptors (trks). NGF acts selectively on trkA, brain-derived neurotrophic factor (BDNF) and neurotrophin-4 (NT-4) on trkB, and neurotrophin3 (NT-3) on trkC. The p75 receptors, which bind all four neurotrophins with similar affinities, may interact with the various trk receptors to enhance ligand specificity and to facilitate signal transduction (Bothwell, 1991, 1995; Chao, 1992; Meakin and Shooter, 1992). Expression of the p75 receptor suggests that one of the neurotrophins may serve as a trophic factor for the avian coeruleus neurons.

We now have investigated the potential neurotrophic regulation of noradrenergic coeruleus neurons in the developing chicken. We have concentrated on late embryonic stages, when targets of the locus coeruleus neurons are accessible in ovo, and up to the age of hatching when the noradrenergic locus coeruleus 
plays an important role in memory processing and imprinting (Davies et al., 1985). This phenomenon has been studied extensively in hatchling chicks (Andrew, 1991; Stephenson, 1991). The aim of the present study is to clarify if coeruleus neurons possess specific, signal-transducing receptors (trks) for neurotrophins, and to test if neurotrophins have effects on coeruleus neurons. We report that the noradrenergic population of the locus coeruleus in chicken embryos heavily expresses the trkA receptor in addition to the p75 neurotrophin receptor, and that the noradrenergic coeruleus neurons retrogradely transport radio-iodinated NGF from the basal forebrain. Administered NGF caused a significant increase in the size of noradrenergic coeruleus neurons in vivo and protected these neurons from toxic effects of 6-hydroxydopamine. These data are consistent with the hypothesis that NGF plays an important role in the development and maintenance of noradrenergic neurons in the chicken locus coeruleus.

Preliminary results of this study have been presented in abstract form (Bothwell et al., 1993; von Bartheld et al., 1994b).

\section{Materials and Methods}

\section{Chick embryos}

Fertilized chicken eggs were purchased from H\&N International (Redmond, WA) or Waldens Poultry (Börje, Sweden). They were incubated in a force-draft incubator at $37-38^{\circ} \mathrm{C}$ and $60-70 \%$ humidity. All animals were staged according to Hamburger and Hamilton (1951). Stages are indicated as days of incubation. A total of about 330 embryos and 3 hatched, 2 week old chicks were used.

\section{In situ hybridization}

Embryos at ages E5, E9, and E18 were frozen over liquid nitrogen and stored at $-80^{\circ} \mathrm{C}$ until used. Serial transverse sections $(10 \mu \mathrm{m})$ through the head or brain (E18) were cut on a cryostat and thaw mounted onto poly-L-lysine coated slides $(50 \mu \mathrm{g} / \mathrm{ml})$. The sections were air dried and stored at $-80^{\circ} \mathrm{C}$ prior to use. To detect mRNA for trk receptors in tissue sections, synthetic oligonucleotide probes complementary to isolated chicken trkA, trkB and trkC cDNAs were used (Scandinavian Gene Synthesis, Köping, Sweden). The oligonucleotide sequence for chicken trkA is 5'-CGG ATG GCT CCT CGG CGT GAA GCT GAA AGG GTT ATC CAT GAA GCG GCC-3', corresponding to amino acid residues 376-391 in the human trkA sequence (Bäckström et al., unpublished observations). The oligonucleotide sequence for the kinase-containing chicken trkB is 5'-GGG CAG CAT GGT GTG ACC CCC AAC CCT GTA GTA GTC TGT GCT GTA CAC-3'. The sequence for the kinase-containing chicken trkC probe is $5^{\prime}$-AGC GGG TCA CCA TCA CCA CAC ACA CCA TAG AAC TTG ACG ATG TGC TCA-3' (for the non-kinase-specific trkC oligosequence and other details, see Williams et al., 1993, 1994). The oligonucleotide probes (50 ng) were labeled at the $3^{\prime}$-end with deoxyadenosine $5^{\prime}-\alpha-{ }^{35} S$-thiotriphosphate (Amersham, Arlington Heights, IL) using terminal deoxynucleotidyl transferase (Promega, Madison, WI) to a specific activity of approximately $1 \times 10^{9} \mathrm{cpm} / \mu \mathrm{g}$. The probes were purified on Nensorb columns (Du Pont, Wilmington, DE) prior to use. Hybridization was performed at $42^{\circ} \mathrm{C}$ for approximately $15 \mathrm{hr}$ in a humidified chamber with $100 \mu \mathrm{l}$ of hybridization cocktail. The hybridization cocktail contained $50 \%$ formamide, $4 \times$ SSC, $10 \%$ dextran sulfate, $0.5 \mathrm{mg} / \mathrm{ml}$ yeast tRNA, 0.06 $M$ dithiothreitol, and $0.1 \mathrm{mg} / \mathrm{ml}$ sonicated salmon sperm DNA. As a control for the specificity, control hybridization solutions included the addition of unlabeled probe at $100 \times$ excess. In addition, controls for cross-hybridization have been performed with $100 \times$ excess of each of the other two unlabeled probes included in the hybridization solution. After hybridization, the slides were washed for $15 \mathrm{~min}$ in $1 \times \mathrm{SSC}$ and $0.05 \%$ sarcosyl, three times for $15 \mathrm{~min}$ each in $0.5 \times \mathrm{SSC}$ at $55^{\circ} \mathrm{C}$ and twice for $1 \mathrm{~min}$ each in cold, RNase-free water. The sections were dehydrated in ethanol, air dried, and coated with Kodak NTB-2 photographic emulsion. After approximately 6 weeks, the emulsion was developed and fixed and the sections lightly counterstained with cresyl violet. Neurons labeled for trkA mRNA were counted in every fifth (E9) or sixth section (E18) and the total number was estimated by using Abercrombie's correction factor for the counting of split cells (Konigs- mark, 1970). For the calculation of the correction factor it was assumed that a labeled cell was recognized only if the cell nucleus was contained within the tissue section. Average nuclear diameters of $7.7 \mu \mathrm{m}$ (E9) and $10.2 \mu \mathrm{m}$ (E18) were assumed for these calculations, based on measurements of p75-immunolabeled coeruleus neurons in frozen sections. Labeled cells were mapped and identified according to the atlas of the chick brain (Kuenzel and Masson, 1988). Components of the locus coeruleus complex are designated as described previously (von Bartheld and Bothwell, 1992; see also Figs. $1 A, 2 A-I)$.

\section{DiI-tracing}

Tracing of neuronal projections was performed both in ovo and postfixation. Postfixation tracing followed the protocol of von Bartheld et al. (1990). DiI crystals were implanted in the telencephalon of E12-17 chick embryos and the DiI was allowed to diffuse along the membranes for $10-12$ months $(n=12)$. For double labeling with antibodies against the p75 receptor, an in vivo protocol was used as follows: DiI was dissolved in $100 \%$ ethanol and injected through a window in the shell into the telencephalon of E15-19 chick embryos $(n=20)$ in a volume of approximately $10 \mu \mathrm{l}$ using $50 \mu \mathrm{l}$ syringes. The animals were allowed to survive for $24-48 \mathrm{li}$, and then were killed with an overdose of Nembutal and perfused intracardially with $4 \%$ paraformaldehyde in phosphate buffer ( $\mathrm{pH} 7.4$ ). The dissected brains were cryoprotected, and frozen sections were cut in the transverse plane at $25-30 \mu \mathrm{m}$ on a cryostat. In some cases, free-floating sections $(50 \mu \mathrm{m})$ were prepared and collected on plain glass slides for screening, and fluorescent neurons in the locus coeruleus (LoC) were photographed. Labeled coeruleus neurons were counted in every third section and mapped after staining these sections with thionin.

\section{Sources of antibodies and neurotrophins}

The monoclonal antibody M7412 (Tanaka et al., 1989) was obtained from Dr. Tanaka (Kumamoto University, Japan). This antibody was later found to be against chicken $\mathrm{p} 75$ receptor $(\mathrm{H}$. Tanaka, personal communication). The hybridoma culture supernatant was diluted 1:2 for immunocytochemistry. Polyclonal antibodies against dopamine- $\beta$-hydroxylase (DBH) were purchased from EugeneTech (Ridgefield, NJ; lot $89 \mathrm{~A}, 2012$, and 8-93) and used at a dilution of $1: 700$ to $1: 1400$. Only lot 2012 recognized chicken DBH. Mouse NGF was prepared according to Mobley et al. (1976). Recombinant human BDNF and NT-3 were kindly provided by Regeneron, Tarrytown, NY (courtesy of Dr. R. Lindsay).

\section{Immunocytochemistry}

Standard innmunocytochemical procedures were applied on sections from either frozen or paraffin-embedded brains. Endogenous peroxidases were inactivated by $0.3 \%$ hydrogen peroxide in methanol. The p75 antibody recognized the antigen only in frozen sections, and superior labeling was obtained in sections processed free-floating. The DBH antibody was successfully applied in paraffin-embedded tissue ( 10 $\mu \mathrm{m}$ sections) and required pretreatment with trypsin $(1 \mathrm{mg} / \mathrm{ml}$, Towle et al., 1984). Secondary antibodies were biotinylated horse anti-mouse $\operatorname{IgG}(1: 500$, Vector Lahs, Burlingame, CA) for the monoclonal antibody, and goat anti-rabbit IgG (1:500, Jackson Immunoresearch Labs, West Grove, PA) for the polyclonals. All sections were incubated with horseradish peroxidase-conjugated streptavidin (1:500, Zymed Labs, South San Francisco, CA) and peroxidase activity was visualized with $0.05 \%$ diaminobenzidine in Tris- $\mathrm{HCl}(\mathrm{pH}$ 7.6) and hydrogen peroxide $(0.0015 \%)$.

\section{Iodination and injection of neurotrophins, processing for autoradiography, and quantification}

The neurotrophins NGF, BDNF, and NT-3 were radio-iodinated with ${ }^{125}$ I using the lactoperoxidase technique (Sutter et al., 1979). The labeled neurotrophins had specific activities of 56.1-112 cpm/pg (NGF), 83.6$124 \mathrm{cpm} / \mathrm{pg}$ (BDNF), and 73.9-114 cpm/pg (NT-3), and they were used within 5 weeks after iodination. Typically, ${ }^{125}$ I-neurotrophins were injected into the telencephalon in a volume of $1-2 \mu l\left(1 \times 10^{6} \mathrm{cpm}\right)$ using Hamilton syringes, and the embryos were allowed to survive for 18-20 hr. They were anesthetized with Nembutal and perfusion fixed with $4 \%$ paraformaldehyde. The dissected brains were dehydrated for paraffin embedding. The amount of radioactivity in the dehydrated brains was measured in a gamma counter (Gamma 5500, Beckman). In 

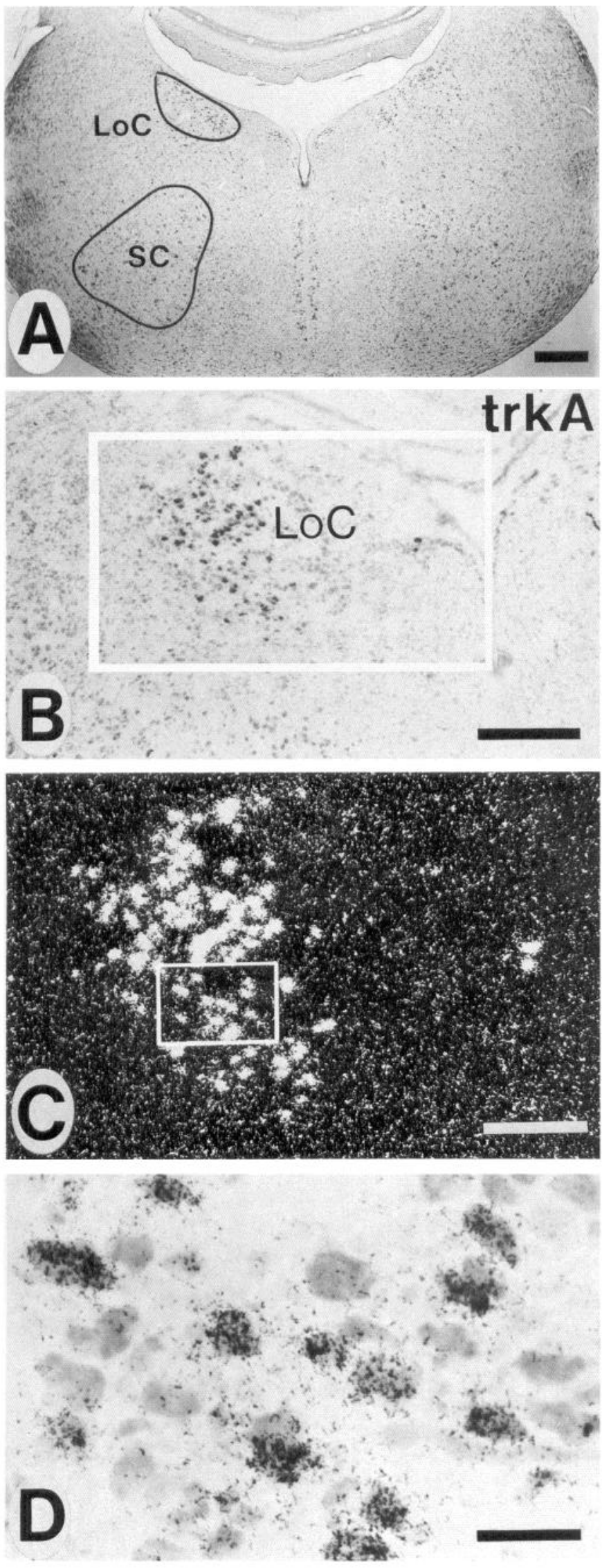

Figure 1. Normal anatomy of the coeruleus system and expression of trkA mRNA in $18 \mathrm{~d}$ old chick embryos (E18). A, Location of the locus successful cases, the injected brains contained 15,000-200,000 cpm. Thirteen brains were selected for further processing (NGF, $n=5$; BDNF, $n=6$; NT-3, $n=2)$. The brains were sectioned $(10 \mu \mathrm{m})$ and processed for autoradiography. Sections were coated with NTB emulsion (Kodak) and exposed for $2-6$ weeks at $4^{\circ} \mathrm{C}$. The relative intensity of labeling in the locus coeruleus complex was quantified by counting silver grains over neurons. In one series, grains were counted in every fifth section over every DBH-labeled neuron with a clearly identifiable nucleus. A grain-frequency profile was established for the LoC, the nucleus subcoeruleus (SC), and the nucleus linearis caudalis (nLC) as a control. Because of the relatively small number of neurons in SC, we did not distinguish between the SC and the caudal part of the SC (SCc, von Bartheld and Bothwell, 1992). The average number of grains/neuron was calculated for the LoC, SC, and nLC. In cases with double labeling ( $n=3$ ), sections were processed for DBH immunocytochemistry prior to autoradiography.

\section{In vitro experiments}

Explant cultures. Six chick embryos of $15 \mathrm{~d}$ of incubation (E15) were decapitated, the brainstems sliced (Masuko et al., 1986) and the LoC was dissected using tungsten needles. Explants of $0.5-1.0 \mathrm{~mm}$ were embedded in collagen gel. The medium was DMEM/F12 (1:1, GIBCO, Grand Island, NY) with 5\% normal horse serum with or without 100 $\mathrm{ng} / \mathrm{ml}$ NGF. Medium (and NGF) were changed at day 3. Explants were maintained up to $6 \mathrm{~d}$ and neurite outgrowth was compared.

Dissociated neurons from locus coeruleus. Tissues containing E12 LoC were collected in Hanks' balanced salt solution (HBSS), and incubated in $0.25 \%$ trypsin in $\mathrm{Ca}^{2+}, \mathrm{Mg}^{2+}$-free $\mathrm{HBSS}$ at $37^{\circ} \mathrm{C}$ for $20-30 \mathrm{~min}$. $\mathrm{LoC}$ neurons were easily damaged and required careful trituration. After dissociation, cells were plated at a density of $5 \times 10^{4} / 19.6 \mathrm{~mm}^{2}$ on coverslips coated with poly-L-ornithine $(25 \mu \mathrm{g} / \mathrm{ml})$ and fibronectin $(20 \mu \mathrm{g} / \mathrm{ml})$ and cultured in Neurobasal medium (supplemented with B27, GIBCO, Grand Island, NY) with or without $50 \mathrm{ng} / \mathrm{ml} \mathrm{NGF}$ or $10 \mathrm{ng} / \mathrm{ml}$ BDNF. Cultures were fixed with $4 \%$ paraformaldehyde after $54 \mathrm{hr}$ and processed for immunocytochemistry with DBH antibody (1:1000) as described above (omitting treatment with trypsin). The yield of DBH-labeled neurons was typically about 250 neurons $/ 50,000$ plated cells. In total, 31 cultures were prepared and 19 were used for detailed analysis.

\section{Injections of $N G F$ in vivo}

Twenty-two chick embryos at $18 \mathrm{~d}$ of incubation were injected in the telencephalon with NGF ( 600 or $1200 \mathrm{ng}$, together with approximately $4000 \mathrm{cpm}$ of ${ }^{125} \mathrm{I}-\mathrm{NGF}$ ). Control embryos were injected with 600 or $1200 \mathrm{ng}$ cytochrome C and $4000 \mathrm{cpm}$ of ${ }^{125}$ I-cytochrome C. Embryos were allowed to survive for $54 \mathrm{hr}$ and then were anesthetized, perfused, and fixed with $4 \%$ paraformaldehyde. The radioactivity in the fore- and hindbrains was measured separately in a gamma counter, and the brains were embedded in paraffin. Brains injected with NGF or cytochrome C were "paired" according to radioactivity counts (to verify comparability of the injections) and every seventh section through the LoC regions of the paired brains was collected adjacent to the other on slides and processed for DBH immunocytochemistry as described above. One or two sets of slides were prepared with paired sections from each brain and processed independently for DBH immunocytochemistry. In five series of sections from each treatment group (paired according to the radioactive counts) the size of the nucleus of each DBH-labeled neuron in the LoC was measured, provided that the nucleus was entirely visible. The same measurements were performed for the SC. Again, because of the relatively small number of neurons in the SC, we did not distinguish between the SC and the SCc (von Bartheld and Bothwell, 1992) for quantitative studies. All sections were coded to prevent examiner bias. The mean of the nuclear

$\leftarrow$

coeruleus $(L o C)$ and nucleus subcoeruleus $(S C)$ in a transverse, Nisslstained section of the chick brainstem at E18. $B-D$, Transverse cryosections through the LoC hybridized for trkA mRNA. B, Low magnification of LoC. Boxed area is shown in dark-field view in $C$. $C$, Note strong hybridization signals over LoC neurons. $D$, Higher magnification of the area boxed in $C$. Note that many but not all neurons in the LoC are labeled. Scale bars: $A, 500 \mu \mathrm{m} ; B, 300 \mu \mathrm{m} ; C, 200$ $\mu \mathrm{m} ; D 50 \mu \mathrm{m}$. 


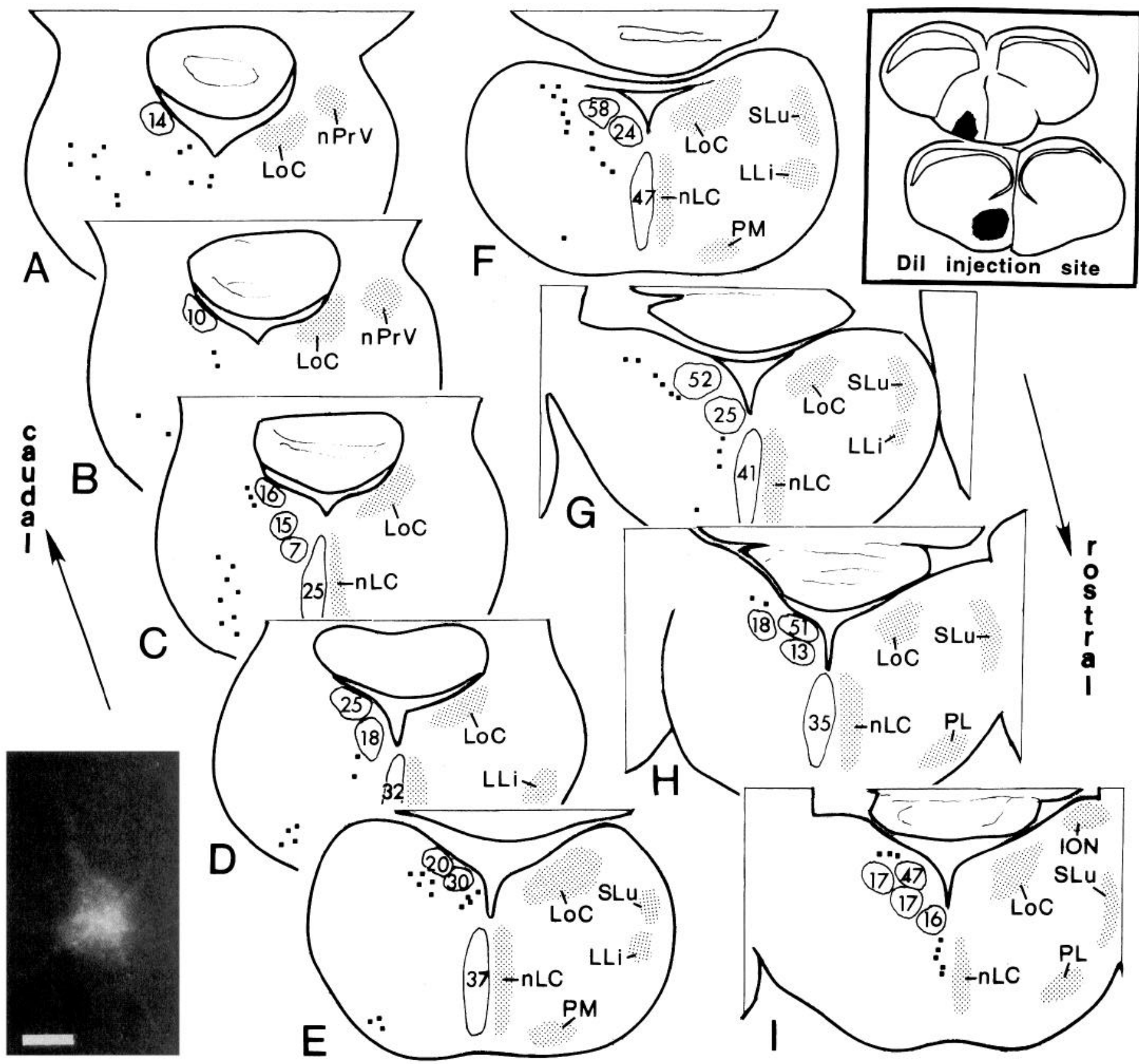

Figure 2. Charts of DiI-labeled neurons in a caudal-rostral series $(A-I)$ of transverse sections through the locus coeruleus complex of a $17 \mathrm{~d}$ old chick embryo after injection of DiI into the basal forebrain. Every third section $(30 \mu \mathrm{m})$ is shown. Numbers indicate the counts of DiI-labeled neurons in the circumscribed areas. Outside these areas, each dot represents one labeled neuron. Labeled neurons are shown for the ipsilateral side only. Note that most labeled neurons are located in the locus coeruleus $(L o C)$ and nucleus linearis caudalis $(n L C)$. The injection site $($ black $)$ is indicated in two transverse sections through the telencephalon (upper right). Photomicrograph (lower left) shows a DiI-labeled neuron in the LoC. Scale bar, $10 \mu \mathrm{m}$. Other abbreviations: $I O N$, isthmo-optic nucleus; $L L i$, nucleus lemnisci lateralis pars intermedia; $n P r V$, nucleus sensorius principalis nervi trigemini; $P L$, nucleus pontis lateralis; $P M$, nucleus pontis medialis; $S L u$, nucleus semilunaris.

diameters was calculated and compared between the treatment groups by $t$ test. In addition, the intensity of DBH immunoreactivity was compared blind as to treatment.

In twenty chick embryos, $150 \mu \mathrm{g}$ of 6-hydroxydopamine (6-OHDA, freshly prepared in phosphate buffer) was coinjected into the telencephalon with either $600 \mathrm{ng}$ of NGF or cytochrome C in a volume of about $6 \mu \mathrm{l}$. In 14 embryos, $150 \mu \mathrm{g}$ of 6-OHDA was injected into the telencephalon and $600 \mathrm{ng}$ NGF was injected into the midbrain. The volumes and doses are similar to those used previously (Ungerstedt, 1971). ${ }^{125}$ I-Cytochrome C $(2000 \mathrm{cpm})$ was coinjected as a marker to verify successful injections and to allow us to estimate the effectively administered doses. The effective dose was calculated according to the formula $E=r / t \times d$, where $E$ is the effective dose of 6-OHDA, $r$ is the amount of radioactivity remaining in the forebrain at the time of sacrifice, $t$ is the total radioactivity injected, and $d$ is the total dose of 6-OHDA that was injected. Usually, the effective dose of 6-OHDA in the forebrain was estimated to be $8-16 \mu \mathrm{g}$. The animals were allowed to survive for $54 \mathrm{hr}$, and selected pairs ( $+\mathrm{NGF} /+$ cytochrome $\mathrm{C}$ ), matched for their radioactivity in the forebrain, were processed for $\mathrm{DBH}$ immunocytochemistry as described above. The number of DBH-labeled neurons with a clearly visible nucleus was counted in every seventh section and the total number of labeled neurons was estimated according to Abercrombie's formula (Konigsmark, 1970). In addition, the size of the nucleus of DBH-labeled coeruleus neurons was measured, averaged, 
and compared for the LoC and the SC (including the SCc). Sections were analyzed blind as to treatment.

\section{Results}

Expression of trk mRNAs in neurons of the locus coeruleus ( $L o C)$

Expression of the $\mathrm{p} 75$ receptor in LoC neurons suggests that these neurons are affected by a neurotrophin but it does not allow one to distinguish which of the neurotrophins may regulate these neurons. To determine which of the signal-transducing neurotrophin receptors are expressed in noradrenergic coeruleus neurons, sections through E5, E9, and E18 locus coeruleus were hybridized with probes for trk receptors. For trkB and trkC transcripts, which exist in forms encoding a tyrosine kinase domain as well as truncated forms lacking this domain, probes were applied which selectively identify the kinase-specific forms in addition to probes which do not distinguish between the two forms.

There was no evident expression of trkA mRNA within the developing LoC region at E5. At E9, trkA mRNA was heavily expressed with $819 \pm 24$ (SD, $n=2$ ) labeled neurons in the LoC on each side. The degree of expression remained similarly intense at E18, the oldest age examined (Fig. $1 A-D$ ). At E18, the LoC contained $861 \pm 118$ (standard deviation, $n=4$ ) trkAexpressing neurons on each side. The labeled neurons occupied a discrete region primarily within the lateral margins of the caudal LoC. No trkA mRNA labeling was seen in the more medially positioned neurons in the caudal region. A smaller number of intensely labeled neurons was observed within the nucleus subcoeruleus (SC) with $85.3 \pm 9.8$ neurons ( $\pm \mathrm{SD}, n=4$ ), excluding the caudalmost part of the nucleus subcoeruleus (SCc). Although the intensity of the labeling for trkA mRNA and the percentage of the labeled neurons within the LoC was high at both $\mathrm{E} 9$ and $\mathrm{E} 18$, it was evident that these neurons comprised only a subpopulation of the entire LoC, since a considerable number of neurons remained unlabeled (Fig. 1D). Because there were no obvious differences in the degree of labeling between individual labeled neurons (in that all neurons which expressed trkA mRNA were labeled very intensely), it is unlikely that those neurons which were considered unlabeled expressed significant, but undetected, levels of trkA mRNA. The number and pattern of distribution of trkA neurons matches the number and distribution of DBH- or p75-labeled neurons in the LoC and the SC (von Bartheld and Bothwell, 1992).

Neurons within the coeruleus complex were lightly labeled with both the kinase-specific and nonspecific trkB probes. Labeling intensity was approximately half that of the trkA-expressing neurons. TrkB-labeled neurons were located throughout the SC, both rostrally and caudally, but only caudally in the LoC, extending to the most caudal boundaries. TrkB-expressing neurons were generally situated more medially than those labeled for trkA. Neurons seem to express the kinase-containing isoform, since the probe which detects both forms of the receptor labeled both neurons and glial cells while the labeling with the kinase-specific probe was only seen in the neurons. This is consistent with previous reports of expression of truncated trkB receptor in glial cells (Frisén et al., 1993). The percentage of trkB-labeled neurons was not specifically determined, although a subjective assessment established that they were fewer in number than the trkA-labeled neurons. Light labeling for trkC mRNA (with both the kinasespecific and the nonspecific probe) was found in the medial parts of SC both rostrally and caudally. Expression of trkC was not evident in glial cells with either trkC probe. Neurons in the medial part of the caudal LoC were lightly labeled; they were situated more medially than the trkA-expression neurons.

\section{Projections of locus coeruleus neurons visualized by the tracer DiI}

The telencephalon is a major target region of locus coeruleus efferents in mammals (Loughlin et al., 1986a,b) and in birds (Tohyama et al., 1974; Kitt and Brauth, 1986). To determine if locus coeruleus neurons project to the forebrain in chicken, the fluorescent tracer DiI was injected into the telencephalon of 15$18 \mathrm{~d}$ old chick embryos (E15-18) in vivo. Many neurons were labeled in the locus coeruleus complex when the injection site included the basal forebrain, up to 800 in the locus coeruleus (LoC, Fig. $2 A-I$ ) and 240 in the SC at E17. In these cases, many neurons were also labeled in the region medial to the LoC as well as in the nucleus linearis caudalis (nLC) and Raphe nucleus, known to contain serotonergic neurons (Dubé and Parent, 1981). Neurons were labeled in the SC only when the injection site encroached into the diencephalon and was not restricted to the telencephalon. Very few neurons were labeled in the LoC when the injection sitc was localized to cortical regions of the telencephalon. To confirm the lack of projections from the embryonic LoC to cortical regions, the telencephalic cortex of fixed embryonic brains (E12-17) was filled with Dil crystals and the tracer was allowed to diffuse for 12 months. In these cases, many neurons were labeled in the tegmentum, in particular in the nucleus mesencephalicus profundus, pars ventralis (MPv), but only occasional neurons were labeled in the LoC. Neurons in the MPV could be labeled as early as E12 (data not shown).

\section{p75 immunocytochemistry}

The noradrenergic subpopulation in the chicken locus coeruleus expresses mRNA for the neurotrophin receptor p75 (von Bartheld and Bothwell, 1992). To determine if these neurons express the 775 receptor protein and to establish a marker for these neurons in double-labeling studies, we used antibody M7412 against chicken p75 (courtesy of Dr. H. Tanaka). Processing of sections on the slide rendered only faint labeling of neurons (data not shown). When applied to free-floating sections, robust labeling was seen throughout the noradrenergic parts of the locus coeruleus complex (LoC and SC, Fig. 3A) which are known to express p75 mRNA. The neurons are large, multipolar and the dendritic processes contain p75 protein (Fig. $3 B$ ). The p75-labeled neurons showed the same characteristic morphology as the catecholamine-fluorescent or DBH-labeled neurons (Guglielmone and Panzica, 1982; von Bartheld and Bothwell, 1992). Three main fiber bundles originate in LoC and SC which are heavily p75-labeled; one is a commissural tract at the rostral level of the LoC (Fig. 3C), the other is an ascending fiber tract in the mesencephalic tegmentum, and the third is a tract that turns dorsally and presumably projects into the cerebellum (data not shown). Commissural fiber systems of the chicken LoC thus resemble those of mammals (Moore and Bloom, 1979). The p75labeled fibers are relatively thick with diameters that range between about 0.5 and $1.0 \mu \mathrm{m}$. P75 was strongly expressed in cell bodies and processes also at P14 (data not shown).

\section{Double labeling with DiI and p75 immunocytochemistry}

To determine if coeruleus neurons with projections to the basal forebrain are noradrenergic, double-labeling experiments were performed. We could not use the $\mathrm{DBH}$-antibody for double la- 

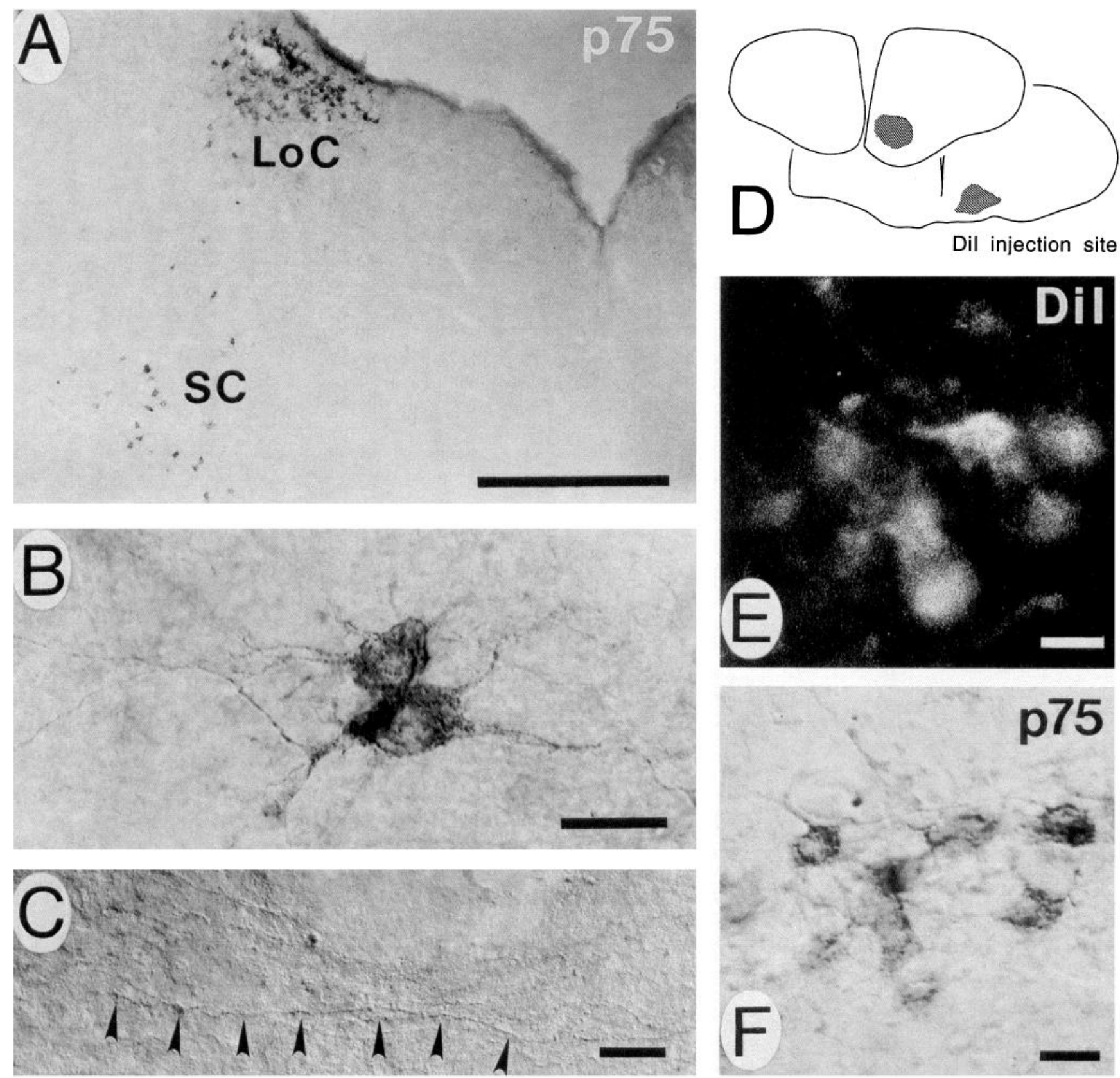

Figure 3. Immunolabeling for the neurotrophin receptor p75 in the locus coeruleus complex of $18 \mathrm{~d}$ old chick embryos (E18). A, Labeled neurons form a distinct subpopulation in the locus coeruleus $(L o C)$ and nucleus subcoeruleus $(S C)$. B, P75 protein is expressed in the soma as well as processes. $C$, P75-labeled fibers originating from the LoC and SC cross the midline at rostral levels of the LoC. $D$, Drawing shows the site of injection of DiI in two transverse sections through the telencephalon in a case with double labeling of LoC neurons with p75 $(E, F) . E$ and $F$, Double labeling of p75 immunoreactive neurons in the locus coeruleus with the fluorescent tracer DiI after injections into the basal forebrain. $E$ shows DiI-label; $F$ shows p75 immunoreactivity in nearly all of the DiI-labeled neurons. The large majority of DiI-labeled neurons express p75. Scale bars: $A, 500 \mu \mathrm{m} ; B, C, E$, and $F, 20 \mu \mathrm{m}$.

beling with DiI, because this antibody does not recognize the antigen in frozen sections. Therefore, we used the p75 antibody as a marker for the noradrenergic neurons. Following injections of DiI into the basal telencephalon of E16-18 chick embryos in vivo (Fig. 3D), as described above, fluorescent neurons in the LoC were photographed. The same sections were processed freefloating with p75 antibody. For technical reasons, double labeling was analyzed only in the LoC, but not in the SC. Three embryos with fortunate injection sites were studied in detail. Many DiI-labeled neurons in the LoC were double labeled with p75 antibody (Fig. 3E,F). Only a few p75-immunoreactive neurons were not DiI labeled. We conclude that many, if not all, noradrenergic, p75-expressing neurons in the LoC project to the basal forebrain in the chick embryo. This conclusion is further supported by experiments with injections of ${ }^{125}$ I-NGF and 6-hydroxydopamine (see below). 

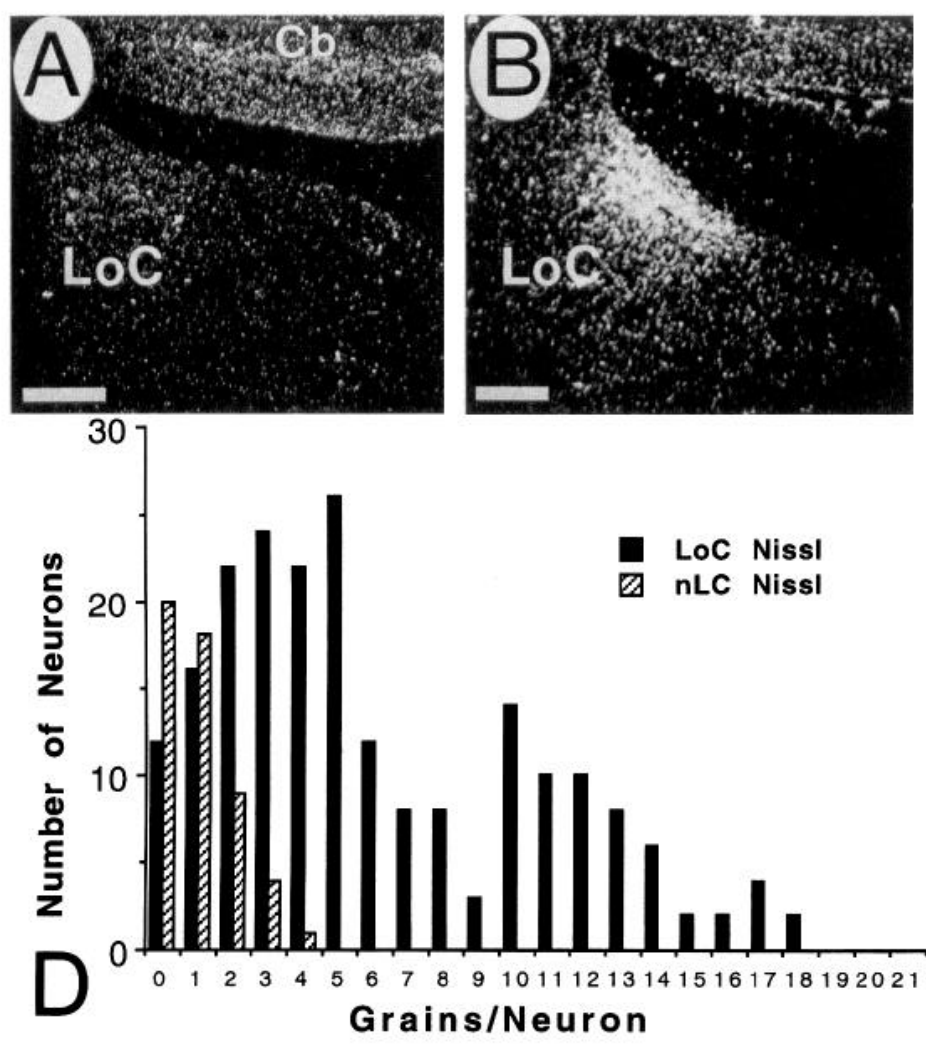

Retrograde transport of ${ }^{125}$ I-labeled neurotrophins to the LoC The ability to internalize and retrogradely transport neurotrophins generally correlates with the capacity for functional responses to neurotrophins. To test if locus coeruleus neurons may internalize and retrogradely transport NGF, BDNF, or NT-3, these neurotrophins were radio-iodinated and injected into the basal forebrain of 14-15 d old chicken embryos. Increased autoradiographic grain densities were consistently detected in the LoC after injections of ${ }^{125} \mathrm{I}-\mathrm{NGF}$ (Fig. $4 B, C$ ), but not after injections of ${ }^{125} \mathrm{I}-\mathrm{BDNF}$ (Fig. $4 A$ ) or ${ }^{125} \mathrm{I}-\mathrm{NT}-3$. Grain counts over Nissl-stained coeruleus cells showed that many, but not all neurons in the LoC were labeled, with an average of $6.3 \pm 0.4$ (SEM) grains/neuron. A control nucleus, the nucleus linearis caudalis (nLC), averaged $1.0 \pm 0.1$ grains/neuron (Figs. $4 C, D$, $5 D$ ). Retrograde transport of NGF could be detected with as little as $0.1 \mathrm{ng}$ of ${ }^{125} \mathrm{I}-\mathrm{NGF}(13,500 \mathrm{cpm})$ in the brain; with 10 times higher amounts of radio-labeled BDNF in the brain $(120,000$ $220,000 \mathrm{cpm}$ ) only relatively sparse label was detected over neurons in the LoC (Fig. 4A). The same batch of ${ }^{125} \mathrm{I}-\mathrm{BDNF}$ was transported efficiently by other neuronal populations in the chick brain (von Bartheld et al., 1993, 1994a). The grain density over LoC neurons was not increased above background after injections of ${ }^{125}$ I-NT-3. In one case of BDNF-injections that included some parts of the optic tectum, a small number of neurons in the region rostral and medial to the LoC was heavily labeled (data not shown). The distribution of neurons with heavy accumulation of BDNF did not overlap with the noradrenergic population, but may correspond to trkB-expressing neurons (Johnson et al., 1993).

\section{Retrograde transport of NGF to DBH-labeled coeruleus neurons}

To determine if the retrograde transport of radio-iodinated NGF is specific for the noradrenergic neurons, or if it is also trans-

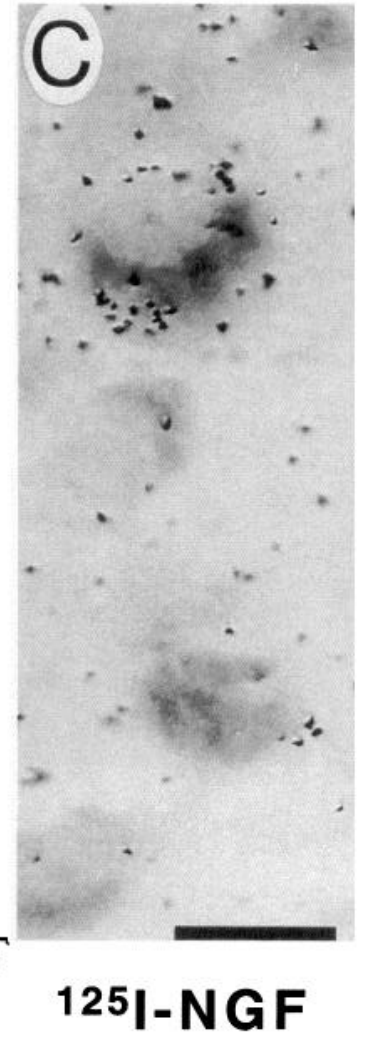

Figure 4. Retrograde transport of ${ }^{125} \mathrm{I}-$ radiolabeled neurotrophins BDNF and NGF to the locus coeruleus $(L o C)$ after injections into the basal forebrain of 15 d old chick embryos. $A$, Transport of ${ }^{125}$ I-BDNF is weak. Note relatively high density of silver grains over the lingula of the cerebellum $(\mathrm{Cb}) . \mathrm{B}$, Transport of ${ }^{125}$ I-NGF to the LoC is extensive. $C$, Higher magnification of Nissl-stained neurons in the LoC after injection of ${ }^{125} \mathrm{I}-\mathrm{NGF}$. Note that some neurons are heavily labeled, whereas others are not labeled. $D$, Grain counts over Nissl-stained neurons in the LoC (solid bars) and nucleus linearis caudalis ( $n L C$, hatched bars) in the same tissue sections after injection of ${ }^{125}$ INGF into the basal forebrain. Scale bars: $A$ and $B, 200 \mu \mathrm{m} ; C, 10 \mu \mathrm{m}$.

ported by coeruleus neurons with other transmitter phenotypes, ${ }^{125}$ I-NGF was injected into the basal forebrain (Fig. 5) and, after sacrifice, series containing every 4 th and 5 th section through the locus coeruleus were processed for DBH immunocytochemistry prior to autoradiography. Accumulation of silver grains was entirely restricted to $\mathrm{DBH}$-labeled neurons in the immunolabeled sections (Fig. 5B). The majority of DBH-positive neurons was radioactively labeled; there was no accumulation of silver grains over neurons lacking DBH label. In one of three cases that were analyzed in detail, grain counts averaged $10.3 \pm 0.3$ (SEM) grains/neuron over DBH-labeled neurons in the LoC, compared with $0.7 \pm 0.2$ (SEM) grains/neuron over control (nLC) neurons (Fig. $5 C, D$ ). There was only a slightly lower number of heavily labeled neurons on the side contralateral to the injection, possibly indicating bilateral projections. Some DBH-labeled neurons in the SC were labeled significantly above background, but they were few in number and less heavily labeled than those in the LoC (Fig. 5C). Grain counts over SC neurons averaged 5.4 \pm 0.4 (SEM) (Fig. 5C,D). The SC neurons therefore seem to contribute to a minor extent to the noradrenergic projections to the forebrain (see also below). Likewise, a small, medially located cluster of DBH-positive neurons appeared to transport ${ }^{125} \mathrm{I}$ NGF only marginally above background. The lightly labeled neurons may not project into the injection site, but may have taken up ${ }^{125} \mathrm{I}-\mathrm{NGF}$ that diffused from the injection site.

\section{Effects of NGF on neurite outgrowth, arborization and DBH expression in vitro}

Arborization of noradrenergic coeruleus neurons is believed to occur between E10 and E17 in chick embryos (Singer et al., 1980). To test if NGF may improve neurite outgrowth in vitro, explant cultures and dissociated neurons from the LoC were treated with NGF. NGF had no consistent effect on the promo- 

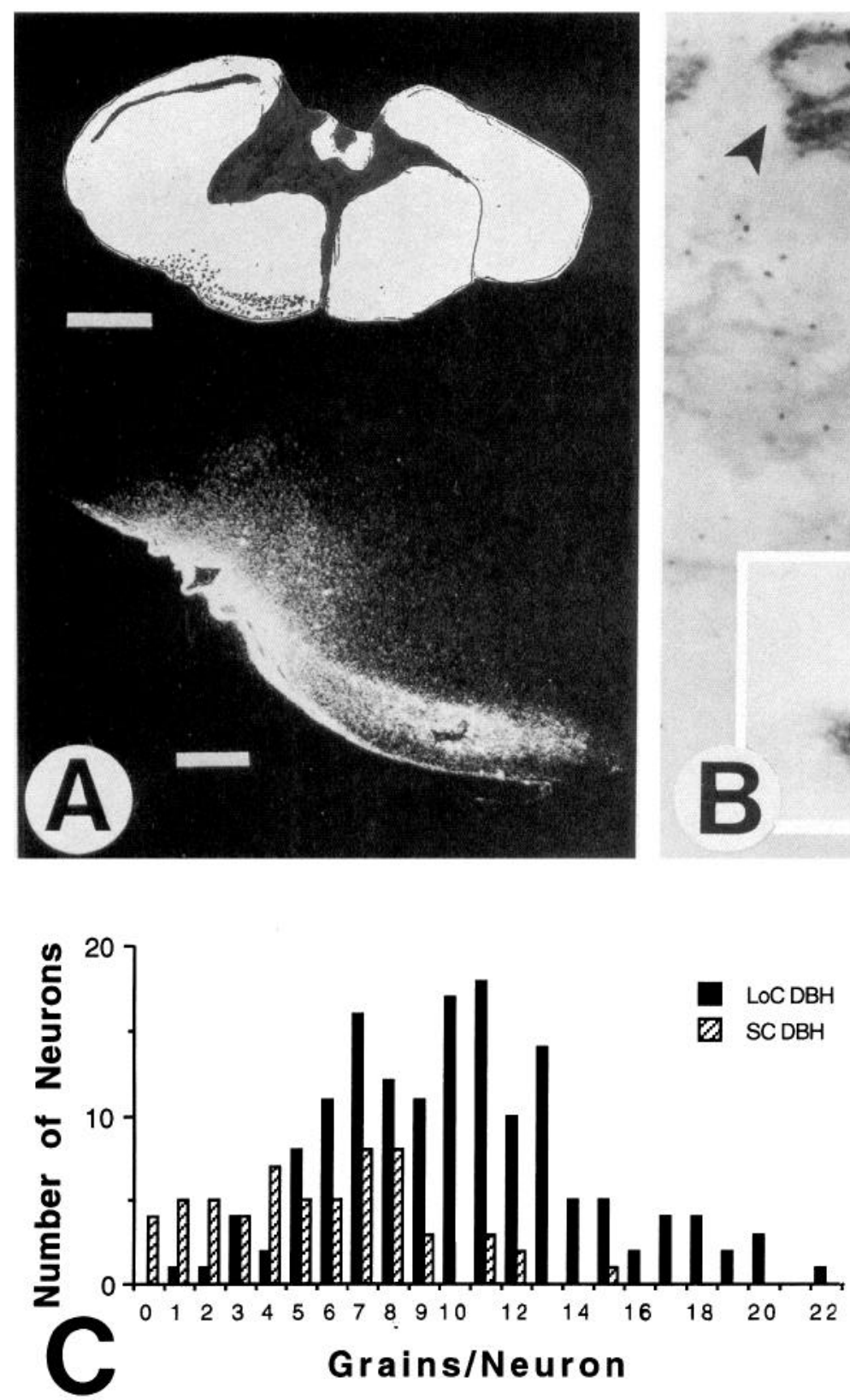
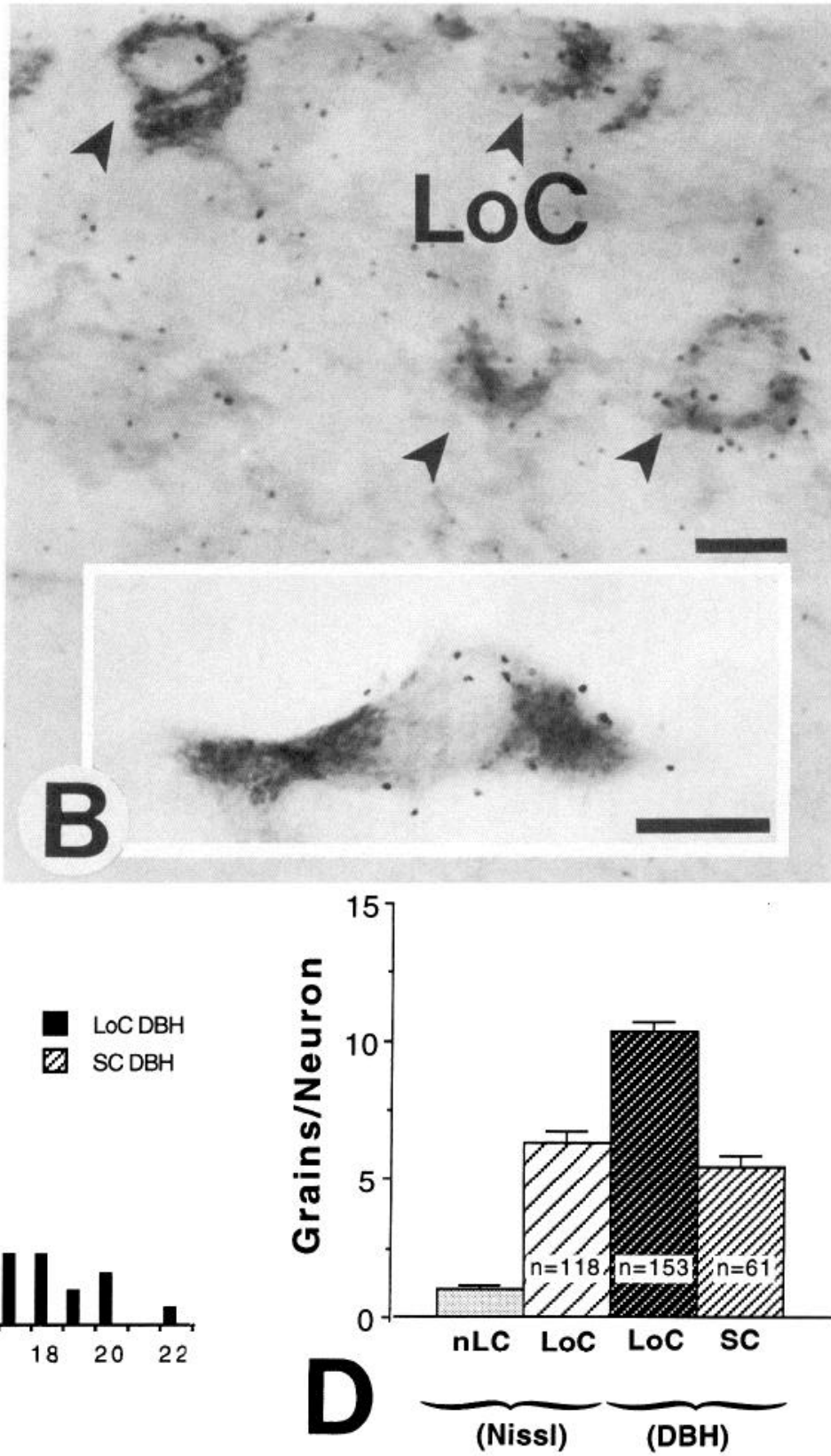

Figure 5. Double labeling with retrogradely transported ${ }^{125}$ I-NGF and immunoreactivity for dopamine- $\beta$-hydroxylase $(D B H)$ in the locus coeruleus complex of $15 \mathrm{~d}$ old chick embryos. A, Injection site of ${ }^{125}$ I-NGF in a transverse section through the basal forebrain. Lower panel shows dark-field view at higher magnification. $B$, The accumulation of silver grains in the locus coeruleus $(L o C)$ is restricted to DBH-labeled cell bodies $($ arrowheads and inset) and their proximal dendrites. $C$, Frequency profile of grain counts over DBH-labeled neurons in the locus coeruleus (LoC, solid bars) and nucleus subcoeruleus (SC, hatched bars). Note that most DBH-labeled neurons in the LoC heavily accumulate ${ }^{125}$ I-NGF, but only few neurons in the SC. $D$, Average grain counts over neurons in the Nissl-stained nucleus linearis caudalis $(n L C)$, in the Nissl-stained LoC, in the DBH-labeled LoC, and in the DBH-labeled SC. Error bars, SEM. The number of neurons sampled are indicated for the LoC and the SC. The differences between all groups (except LoC-Nissl and SC-DBH) are statistically significant ( $t$ test) at $p<0.0005$. Scale bars: upper panel A, 1 mm; lower panel A, 200 $\mu \mathrm{m} ; B, 10 \mu \mathrm{m}$.

tion of neurite outgrowth from E15 LoC explants (data not shown). In dissociated cell cultures from E12 LoC, the number of DBH-labeled neurons was not increased after $54 \mathrm{hr}$ with NGF, and the cell size, number of processes, length of processes and amount of arborization of DBH-labeled neurons did not appear to be significantly increased compared to control cultures (Fig. $6 A, B)$. Neither was the intensity of $\mathrm{DBH}$ label increased in the NGF-treated cultures compared with controls (Fig. 6A,B).
Effects of $N G F$ on nuclear size and $D B H$ expression in vivo To test if NGF may induce hypertrophy or an increase in DBH expression of noradrenergic coeruleus neurons in vivo, NGF was injected into the telencephalon of E18 chick embryos. Injections that resulted in an estimatcd $20-23$ ng of exogenous NGF in the brain of chick embryos significantly increased the size of DBHlabeled neurons in the LoC compared to embryos with injections of cytochrome $\mathrm{C}$. Both the soma and the nucleus of noradren- 

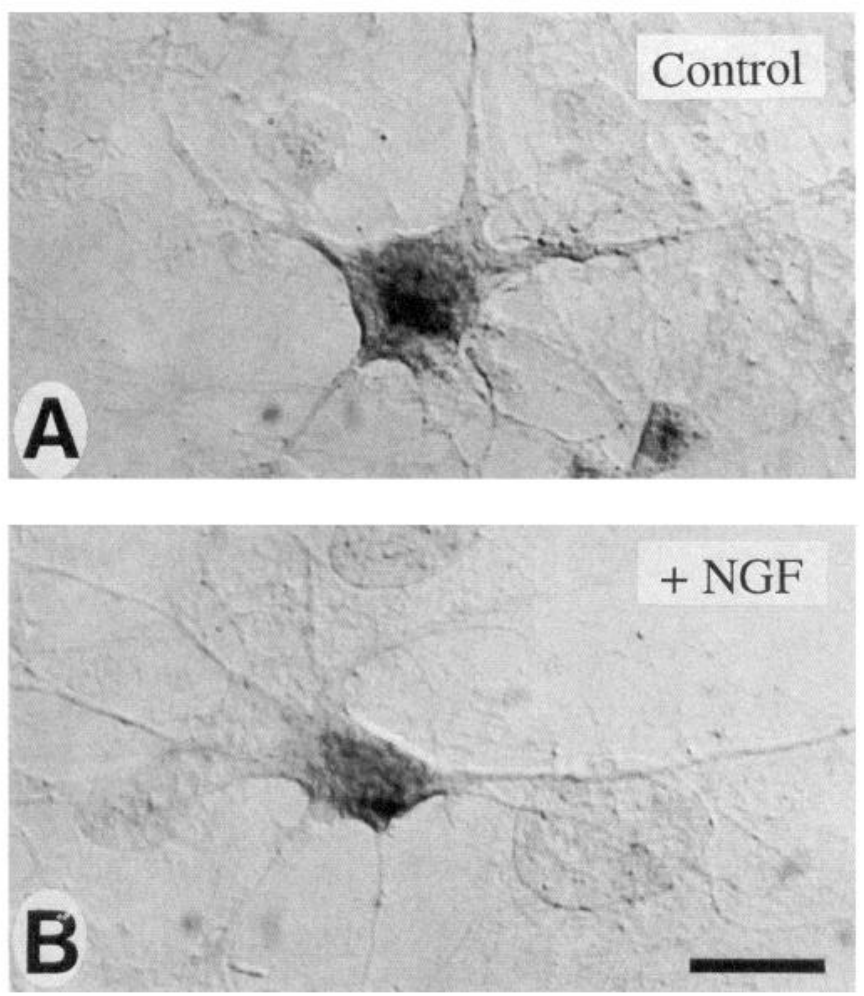

Figure 6. Dissociated cells from the locus coeruleus of $12 \mathrm{~d}$ old chick embryos after $54 \mathrm{hr}$ in culture treated without NGF $(A)$ or with $50 \mathrm{ng} / \mathrm{ml}$ NGF $(B)$. Cultures were labeled with an antibody against dopamine- $\beta$ hydroxylase (DBH). Note the apparent lack of an effect of NGF on neurite outgrowth, morphology or survival of noradrenergic coeruleus neurons. Scale bar, $10 \mu \mathrm{m}$.

ergic LoC neurons were larger in average than those in control animals (Fig. 7A,B). The increase in the size of the nucleus was quantified in the LoC and in the SC by measuring the diameter of DBH-labeled coeruleus neurons (Table 1). The average nuclear diameters in the LoC increased from $7.93 \pm 1.81(\mathrm{SD}, n$ $=304)$ to $9.08 \pm 1.71(n=352$, Fig. $7 C)$. The increase in the nuclear size of noradrenergic LoC neurons is statistically significant ( $p<0.0005, t$ test). There was no increase, but rather a slight decrease in the average size of the nuclei of DBH-labeled neurons in the SC after injections of NGF into the telencephalon, from $8.88 \pm 1.39(\mathrm{SD}, n=278)$ to $8.43 \pm 1.28(n$ $=159$, Fig. $7 D$ ). The intensity of $\mathrm{DBH}$ label in LoC neurons was not consistently increased after treatment with NGF (Fig. $7 A, B)$.

\section{Effects of 6-hydroxydopamine and NGF on DBH-labeled coeruleus neurons}

NGF protects noradrenergic sympathetic neurons from the toxic effects of 6-hydroxydopamine (6-OHDA, Levi-Montalcini et al., 1975). To test if NGF may protect noradrenergic coeruleus neurons, the forebrains of E17 embryos were injected with $150 \mu \mathrm{g}$ of 6-OHDA, and either the forebrain or the midbrain was injected with NGF or cytochrome C. To verify the injections into the forebrain, ${ }^{125} \mathrm{I}$-labeled cytochrome $\mathrm{C}$ was coinjected with the 6-OHDA and the amount of radioactivity was measured post mortem. This allowed us to estimate the effective doses and to pair similarly successful injections. There was no significant effect of cytochrome $\mathrm{C}$ injections on the number or size of DBH- labeled neurons in the LoC or SC. An effective dose of 8-16 $\mu \mathrm{g}$ of $6-\mathrm{OHDA}$ in the forebrain decreased the number of $\mathrm{DBH}$ labeled neurons in the LoC by about $30-70 \%$ (Fig. $8 D$ ), but not in the SC which does not have major projections to the telencephalon. While DBH-labeled neurons in the ventral SC consistently appeared normal, in two cases (in which $75-90 \%$ of DBHlabeled neurons were lost in the LoC) most of the remaining neurons in the LoC and some neurons in the dorsal SC were smaller in size or pyknotic (data not shown).

The noradrenergic coeruleus neurons remained intact despite 6-OHDA treatment when NGF was injected at the same time as 6-OHDA, but into a different target of the LoC within the brain (Fig. 8A-C). Counts of the noradrenergic neurons in the LoC showed that NGF rescued a large number of these neurons from the toxic effects of 6-OHDA, with increases of about $100 \%$ compared with controls (=cases with $6-$ OHDA only or NGF coinjected into the "poisoned" telencephalon, Fig. 8D). Coinjection of 6-OHDA and NGF in the telencephalon appeared to kill more LoC neurons than injection of 6-OHDA alone (Fig. 8D), although this effect was not statistically significant. By contrast, when NGF was injected into the midbrain $(n=4)$, another target of the avian LoC (Rodman and Karten, 1991), it had a significant protective effect on noradrenergic neurons $(p<0.05$, when compared with the combined groups, 6-OHDA only and $6-O H D A+N G F$ in the telencephalon, $n=6$ ). The effect of NGF is likely direct, via binding of NGF to trkA-expressing LoC neurons or to their collaterals in the optic tectum (Rodman and Karten, 1991), because LoC neurons are the only cells in the brain with significant trkA expression. The protective effect of NGF was further quantified by measuring the diameter of DBHlabeled neurons. Neurons in the LoC treated with 6-OHDA had nuclei with significantly larger diameters when NGF was injected into the midbrain than those of neurons from animals treated with 6-OHDA alone (Fig. 8E). Coinjection of NGF with the toxin into the same target did not counteract the detrimental effects of 6-OHDA on DBH-labeled neurons (Fig. $8 D, E$ ), possibly because the axonal processes of LoC neurons eventually degenerated in the forebrain due to the toxic effects of 6-OHDA and therefore could not transport and mediate the trophic signal of NGF to the cell bodies in the LoC.

\section{Discussion}

Evidence for the expression of functional NGF receptors in the locus coeruleus

The distribution and number of trkA-expressing neurons in the locus coeruleus (LoC) are strikingly similar to those revealed with antibodies against DBH or p75 (von Bartheld and Bothwell, 1992). It is obvious that the large majority of, if not all, coeruleus neurons with expression of NGF receptors are noradrenergic. Both types of NGF receptors are expressed at remarkably high levels. Levels of expression of trkA and p75 in the LoC exceed those of all other neuronal populations in the chicken CNS (present study; von Bartheld et al., 1991a).

Target structures of the LoC in the chicken CNS include the telencephalon, the optic tectum, the cerebellum and the brainstem (Mugnaini and Dahl, 1975; Singer et al., 1980; Yurkewicz et al., 1981b; present study). These regions express NGF mRNA in the developing chick (Ebendal et al., 1986; Large et al., 1989), but the specific cell populations responsible for the detected expression remain to be identified. The basal telencephalon contains larger amounts of NGF mRNA than the cortical regions, and levels increase in the basal telencephalon and diencephalon 
Figure 7. Effects of NGF on noradrenergic coeruleus neurons in vivo. Injections of NGF into the telencephalon induce hypertrophy of neurons in the locus coeruleus $(\mathrm{LoC})$ labeled with an antibody against dopamine- $\beta$-hydroxylase (DBH). A, Control LoC after injections of cytochrome C. B, NGFtreated LoC. Note the increased size of the cell bodies and nuclei of DBH-labeled neurons. The intensity of immunoreactivity for DBH was not consistently increased after NGF injections. Scale bar, $10 \mu \mathrm{m}$. $C$ and $D$, Quantification of the increase in nuclear diameter of noradrenergic neurons after injections of NGF into the telencephalon. Values are averages from five independent paired experiments. Nuclear sizes are significantly increased in the LoC which projects to the telencephalon, but not in the nucleus subcoeruleus $(S C)$ which does not project to the telencephalon. Error bars, SEM.
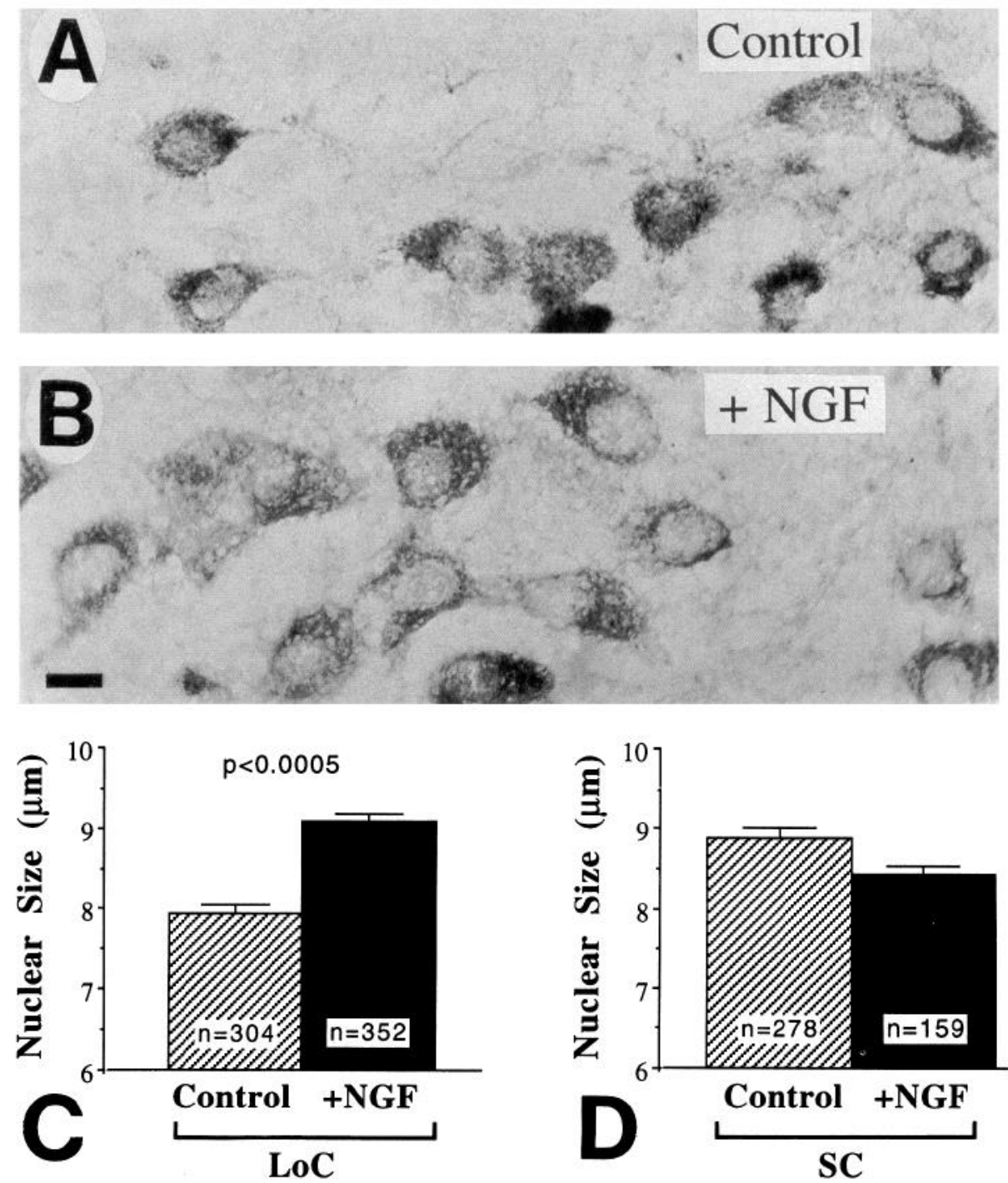

Table 1. Average nuclear diameter of noradrenergic neurons in the locus coeruleus of chick embryos after injections of cytochrome C or NGF into the forebrain at E18

\begin{tabular}{|c|c|c|c|c|c|}
\hline \multirow[b]{2}{*}{ Animal } & \multirow{2}{*}{$\begin{array}{l}\text { Age at } \\
\text { sacrifice }\end{array}$} & \multicolumn{2}{|c|}{ Actual dose (ng) } & \multirow{2}{*}{$\begin{array}{l}\text { Nuclear } \\
\text { diameter }(\mu \mathrm{m})\end{array}$} & \multirow{2}{*}{$\begin{array}{l}n \\
\text { (neurons) }\end{array}$} \\
\hline & & Cyto. C & NGF & & \\
\hline \multicolumn{6}{|c|}{ +Cyto. C } \\
\hline 41.22 & E21 & 10.2 & 一 & 8.240 & 75 \\
\hline 41.30 & E19 & 16.1 & - & 7.830 & 47 \\
\hline 41.28 & E20 & 16.8 & - & 8.652 & 66 \\
\hline 41.43 & E20 & 25.2 & - & 7.105 & 57 \\
\hline 41.47 & E20 & 27.9 & 一 & 7.627 & 59 \\
\hline \multicolumn{6}{|l|}{$+\mathrm{NGF}$} \\
\hline 41.20 & E21 & - & 10.5 & 8.442 & 95 \\
\hline 41.42 & E20 & - & 20.0 & 9.126 & 140 \\
\hline 41.31 & E21 & - & 21.9 & 9.980 & 50 \\
\hline 41.38 & E20 & - & 22.5 & 9.507 & 67 \\
\hline
\end{tabular}

from E13 to P1 (Large et al., 1989). In the PNS, expression of NGF correlates with the density of innervation by NGF-responsive sympathetic neurons (Korsching and Thoenen, 1983; Ebendal et al., 1986). It will be interesting to determine which neuronal populations in the CNS express NGF and to examine if NGF production correlates with the extent of innervation from the noradrenergic LoC.

Internalization of neurotrophins is believed to require highaffinity binding of the ligands (Bernd and Greene, 1984; Meakin and Shooter, 1992). High affinity binding sites for NGF have either been ascribed to trkA receptors (Klein et al., 1991) or to the result of interactions between p75 and trkA receptors (Hempstead et al., 1991). The noradrenergic neurons in the chick LoC express both p75 and trkA receptors. It is therefore surprising that NGF does not appear to bind with high affinity to the LoC in chick embryos (Raivich et al., 1987). Immunocytochemical data with p75 antibodies (Fig. $2 B$ ) and preliminary data with 

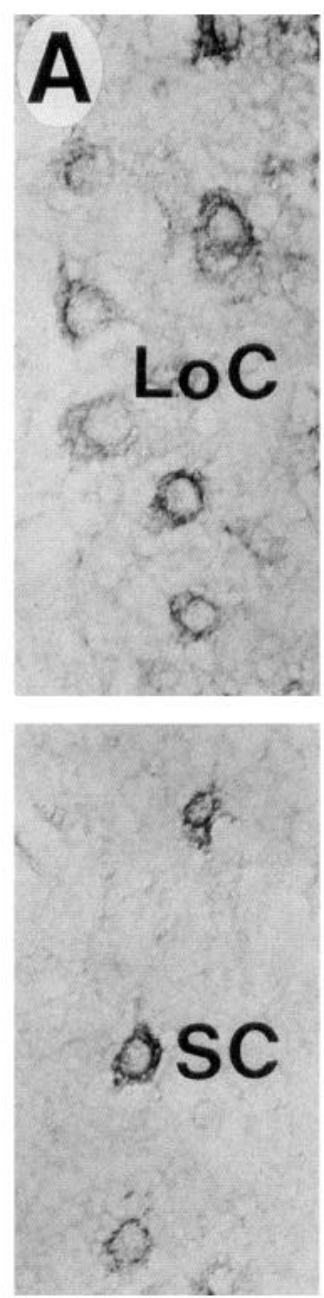

Control
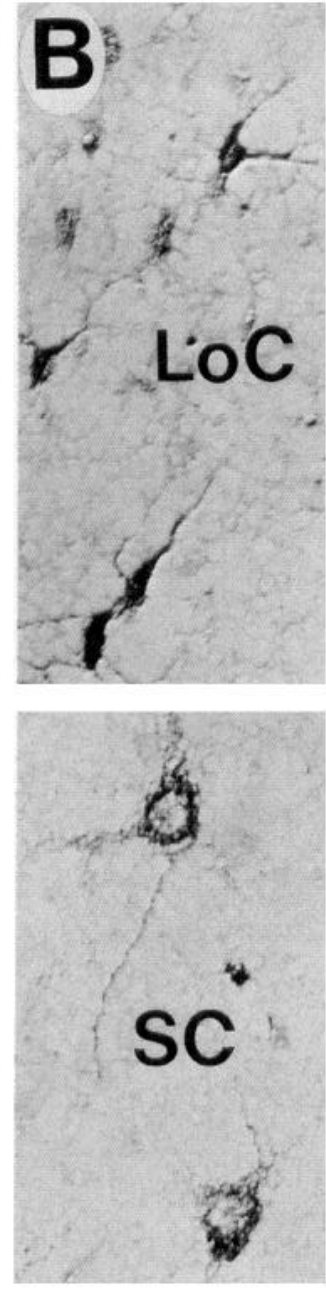

+ 6-OHDA
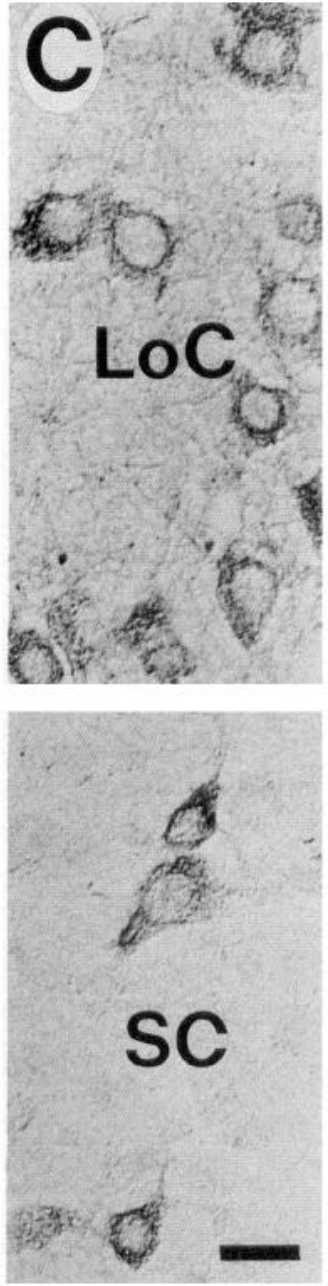

6-OHDA + NGF
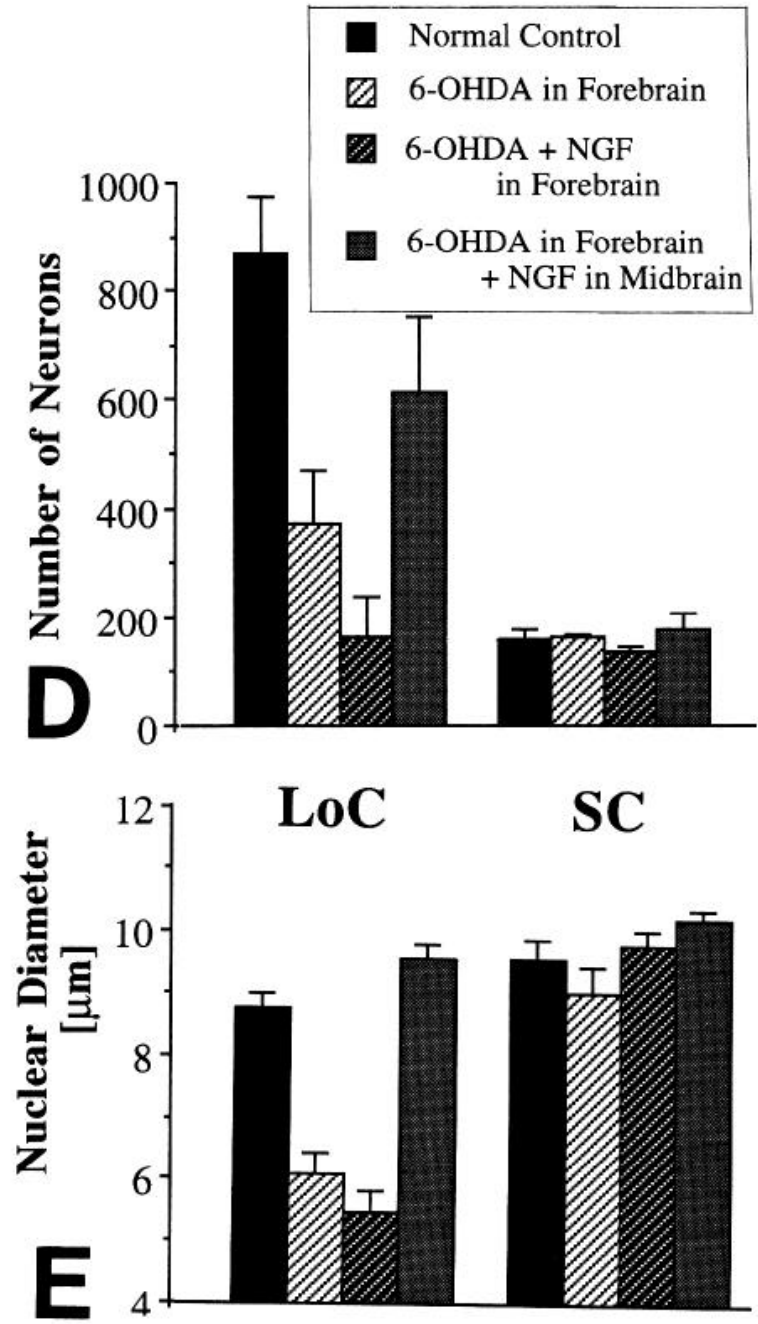

1

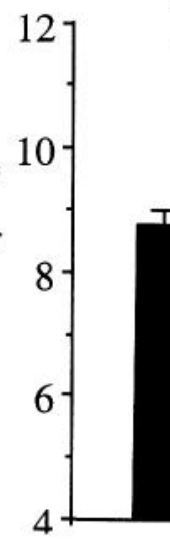

LoC

SC

Figure 8. Protection of noradrenergic coeruleus neurons in E19 chicken embryos by administration of NGF. The upper panels of $A-C$ show DBHlabeled neurons in the locus coeruleus $(\mathrm{LoC})$, the lower panels show DBH-labeled neurons in the nucleus subcoeruleus ( $S C$ ). Micrographs in the upper and lower panels for each treatment group are from the same tissue section. $A$, Coeruleus neurons in a normal E19 chick embryo. $B$, Coeruleus neurons in an embryo that was injected with 6-hydroxydopamine (6-OHDA) into the telencephalon. Note the smaller size and small number of surviving neurons. The DBH-labeled neurons in the SC are not affected. $C$, Coeruleus neurons in an embryo that was injected with 6-OHDA into the forebrain, and with NGF into the midbrain. Note that NGF prevented the toxic effect of 6-OHDA. Scale bar for all panels $A-C: 20 \mu \mathrm{m}$. $D$ and $E$, Counts of DBH-labeled neurons $(D)$ and measurements of their nuclear diameter $(E)$ in the LoC and SC in normal E19/20 embryos $($ solid bars), embryos with injection of 10-16 $\mu \mathrm{g}$ of 6-OHDA into the forebrain (lightly hatched bars), embryos with 12-15 $\mu \mathrm{g}$ of 6-OHDA and about 50 ng NGF coinjected into the forebrain (darkly hatched bars), and embryos with 10-15 $\mu \mathrm{g}$ of 6-OHDA injected into the forebrain and approximately $50 \mathrm{ng}$ of NGF into the midbrain (gray bars). Error bars, SEM; $n$ for each group with different treatment, $4-6$. Note that the injection of NGF into the midbrain, but not into the forebrain, increased the numbers and nuclear diameters of surviving noradrenergic neurons in the LoC after administration of 6-OHDA.

trkA antibodies indicate that these receptors are present in the cell bodies as well as in neurites, ruling out the possibility that the receptors may be targeted selectively to the neurites as it occurs in some other neuronal populations with p75 receptors (von Bartheld et al., 1991b). Moreover, noradrenergic LoC neurons internalize and transport NGF retrogradely after injections into the forebrain (Figs. 4, 5). The heterogeneity of neuronal populations in the chicken locus coeruleus complex with regard to transmitter phenotypes (von Bartheld and Bothwell, 1992) appears to be reflected by heterogeneity in the expression of neurotrophin receptors, retrograde transport of neurotrophins, and efferent projections.

\section{Effects of NGF on noradrenergic neurons in the CNS and} comparison with the PNS

The noradrenergic neurons in the CNS develop precociously (Lauder and Bloom, 1974; Yurkewicz et al., 1981a; von Bartheld and Bothwell, 1992). At E6, the noradrenergic phenotype is already expressed (von Bartheld and Bothwell, 1992), and trkA expression becomes evident between E5 and E9 (present study). The number of trkA-expressing, presumptive noradrenergic neurons does not seem to decrease during development in chick embryos. Thus, there is no indication that a fraction of initially noradrenergic CNS neurons subsequently becomes cholinergic, as it occurs in sympathetic PNS neurons (Landis, 1990). Also, 
the onset of trkA receptor expression (between E5 and E9) and the appearance of DBH label (prior to E6, von Bartheld and Bothwell, 1992) do not suggest that NGF induces the noradrenergic phenotype in chick coeruleus neurons.

The expression of high affinity binding sites is generally assumed to indicate that the corresponding neurotrophin acts as a survival factor (but see Dechant et al., 1993). However, trkA does not seem to be necessary for the survival of NGF-responsive cholinergic forebrain neurons in mammals (Smeyne et al., 1994). There is no evidence for developmental cell death in LoC neurons (Cowan et al., 1984; von Bartheld and Bothwell, 1992), but many neuronal populations of the reticular type, including the LoC, are affected by degenerative brain diseases (Bondareff et al., 1982; German et al., 1992) which may involve trophic mechanisms (Appel, 1981; Saper et al., 1987). Consistent with the view that neurotrophins play a role in the maintenance of coeruleus neurons is our finding that NGF protects noradrenergic neurons in the chicken LoC against the action of a neurotoxin and the recent report that NT-3 similarly prevents the degeneration of neurons in the mammalian LoC (Arenas and Persson, 1994).

In the PNS, NGF affects several aspects of development, maturation and maintenance of noradrenergic neurons, including neurite outgrowth, hypertrophy, and increases in the activity of tyrosine hydroxylase and DBH (Levi-Montalcini and Cohen, 1956, 1960; Thoenen et al., 1971; Campenot, 1982). The effect of NGF on peripheral neurons is not restricted to the developmental period: NGF can change levels of neuropeptides in the adult (Lindsay and IIarmar, 1989) as well as in the embryo (Hayashi et al., 1985). Consistent with the finding that systemically administered NGF induces hypertrophy of trkA-expressing neurons in the rodent CNS (Holtzman et al., 1994), we demonstrate a substantial increase in the cell size and nuclear size of DBH-labeled neurons in the LoC of chick embryos after injection of NGF into the telencephalon in vivo. These experiments provide direct evidence that increased levels of NGF in the target are sufficient to induce hypertrophy of developing neurons, a result that supports the neurotrophic hypothesis (Purves, 1988). Systemic injections of NGF protect catecholaminergic neurons in the PNS from some of the toxic effects of 6-hydroxydopamine (6-OHDA, Levi-Montalcini, 1974; Levi-Montalcini et al., 1975). Consistent with this finding, we show that NGF protects noradrenergic coeruleus neurons when NGF is administered to a different target of the LoC (the optic tectum, Rodman and Karten, 1991) than the toxin.

We did not observe effects of NGF on DBH-labeled neurons from the chick LoC in vitro. This may be due to technical reasons: glial cells express NGF in vitro (Lindsay, 1979; Lu et al., 1991) which may stimulate noradrenergic neurons maximally, thereby obscuring effects of exogenous NGF. Alternatively, the in vitro situation may not adequately reflect the in vivo situation (Oppenheim et al., 1991).

Noradrenergic innervation of the forebrain in birds: a role for NGF in synaptic plasticity?

The noradrenergic innervation of the forebrain is of particular interest because of the involvement of the telencephalon in learning, imprinting, and memory processing (Kety, 1970; Mason, 1984; Davies et al., 1985; Gordon et al., 1988; Stephenson, 1991). Noradrenaline has been implicated in mechanisms of plasticity and certain forms of memory processing (Foote et al., 1983; Mason, 1984). The noradrenergic neurons display a con-
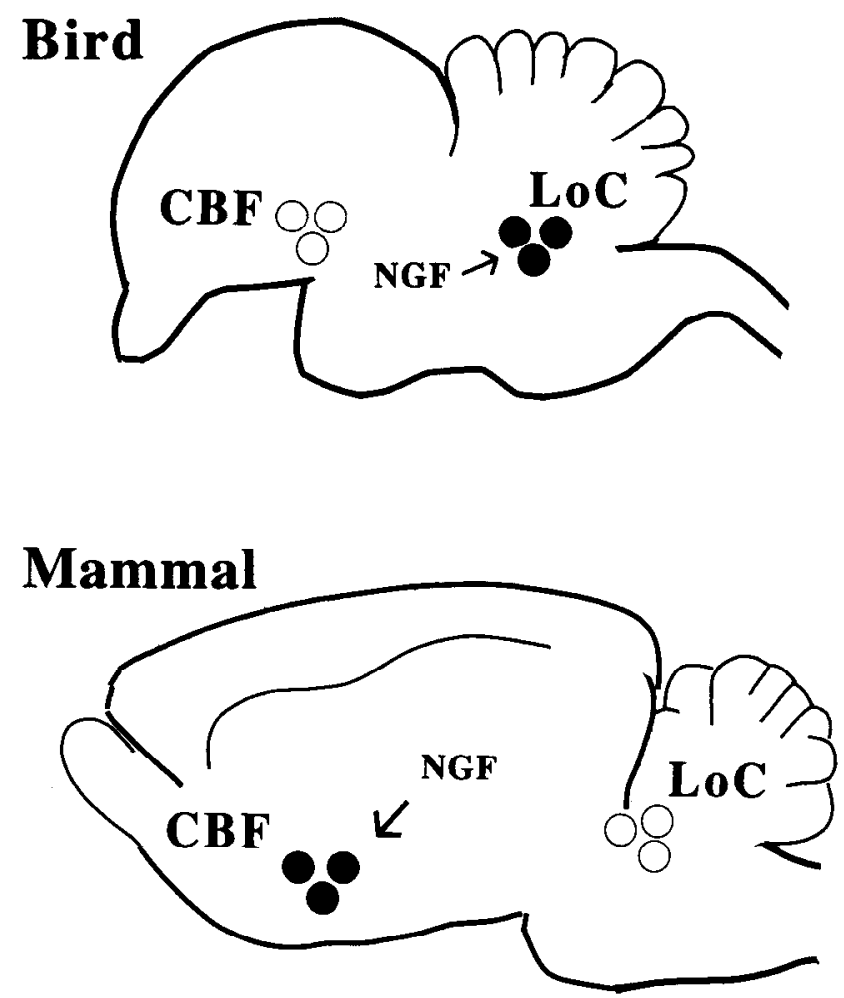

Figure 9. Species differences in the trophic phenotypes of reticular CNS neurons in birds (chicken) and mammals. Noradrenergic coeruleus neurons $(L O C)$ are the main NGF-dependent reticular system in the avian CNS, whereas cholinergic basal forebrain $(C B F)$ neurons are the main NGF-dependent reticular system in the mammalian CNS. While the $\mathrm{LOC}$ in birds and the CBF in mammals apparently are regulated by the same trophic factor $(N G F)$, this does not imply that the two nuclei necessarily perform the same function in the two classes of vertebrates.

siderable degree of plasticity; sprouting and axon elaboration have been shown in the mature brain following lesions (Stenevi et al., 1973) or external stimulation (Nakamura and Sakaguchi, 1990). Since levels of mRNA for trophic factors can increase dramatically as a result of stimulation (Zafra et al., 1990; Patterson et al., 1992), noradrenergic LoC neurons may react to local activity and release of neurotrophins by target neurons with increased sprouting and/or release of noradrenaline. In the telencephalon of chicks, levels of noradrenaline increase during the first days after hatching (Davies et al., 1983). In support of the view that NGF may be involved in processes related to memory (Barde, 1989; Thoenen, 1991), we have shown that both classes of NGF receptors, p75 and trkA, are expressed in the noradrenergic coeruleus population, and that target-derived NGF increases the size of neurons which express $\mathrm{DBH}$, the rate-limiting enzyme in the synthesis of noradrenaline.

\section{Trophic phenotype of the noradrenergic LoC: evidence for evolutionary divergence}

In mammals, the noradrenergic neurons in the LoC do not transport NGF (Schwab et al., 1979), these neurons normally do not express p75 receptors (Koh et al., 1989; Pioro and Cuello, 1990) or trkA receptors (D.M. Holtzman, personal communication), and the intact nucleus does not respond to NGF (Konkol et al., 1978; Olson et al., 1979; Dreyfus et al., 1980; Whittemore and Seiger, 1987; Arenas and Persson, 1994). Ironically, the LoC was initially expected to be the most likely NGF-responsive nu- 
cleus in the CNS because of its transmitter phenotype which is identical to that of the NGF-dependent sympathetic ganglia of the PNS (Stenevi et al., 1973, 1974; Freed, 1976; Schwab et al., 1979). 'The earliest studies on the effects of NGF in the mammalian CNS indeed reported that the lesioned LoC responded to NGF (Björklund and Stenevi, 1972; Bjerre et al., 1973, 1974; Stenevi et al., 1974).

Our study establishes a major species difference between birds and mammals in the trophic phenotype of noradrenergic coeruleus neurons. In chicken, noradrenergic LoC neurons express trkA and p75 receptors, and these neurons transport NGF and respond to NGF; the homologous neurons in mammals express trkC receptors and respond to NT-3 (Merlio et al., 1992; Friedman et al., 1993; Arenas and Persson, 1994). In contrast, a different reticular nucleus in the mammalian brain, the cholinergic basal forebrain, expresses trkA and $\mathrm{p} 75$ receptors and is NGF dependent, whereas the presumptive homologous population in the chicken basal telencephalon does not express p75 or trkA, but rather expresses the fibroblast growth factor receptor 1 (Heuer et al., 1990; von Bartheld and Bothwell, 1992) (Fig. 9). These trophic differences may reflect species differences in the development (Landis, 1988) and the evolutionary history of cholinergic and catecholaminergic systems (Parent et al., 1984). Our studies indicate that trophic properties of neurons may be quite "plastic" on a phylogenetic time scale (Ebendal, 1992). The apparent differences in expression of trophic receptors remind us that trophic requirements of neuronal populations can not be extrapolated across species.

\section{References}

Andrew RJ (1991) Neural and behavioral plasticity. The use of the domestic chick as a model. London: Oxford UP.

Appel SH (1981) A unifying hypothesis for the cause of amyotrophic lateral sclerosis, parkinsonism, and Alzheimer's disease. Ann Neurol 10:499-505.

Arenas E, Persson H (1994) Neurotrophin-3 prevents the death of adult central noradrenergic neurons in vivo. Nature 367:368-371.

Barde YA (1989) Trophic factors and neuronal survival. Neuron 2:1525-1534.

Bernd P, Greene LA (1984) Association of ${ }^{125}$ I-nerve growth factor with PC12 pheochromocytoma cells. Evidence for internalization via high-affinity receptors only and for long-term regulation by nerve growth factor of both high- and low-affinity receptors. J Biol Chem 259:15509-15516.

Bjerre B, Björklund A, Stenevi U (1973) Stimulation of new axonal sprouts from lesioned monoamine neurones in adult rat brain by nerve growth factor. Brain Res 60:161-176.

Bjerre B, Björklund A, Stenevi U (1974) Inhibition of the regenerative growth of central noradrenergic neurons by intracerebrally administered anti-NGF serum. Brain Res 74:1-18.

Björklund A, Stenevi U (1972) Nerve growth factor: stimulation of regenerative growth of central noradrenergic neurons. Science 175 : 1251-1253.

Björklund A, Johansson B, Stenevi U, Svendgaard N-A (1975) Reestablishment of functional connections by regenerating central adrenergic and cholinergic axons. Nature 253:446-448.

Bondareff W, Mountjoy CQ, Roth M (1982) Loss of neurons of origin of the adrenergic projection to cerebral cortex (nucleus locus coeruleus) in senile dementia. Neurology 32:164-168.

Bothwell M (1991) Keeping track of neurotrophin receptors. Cell 65: 915-918.

Bothwell M (1995) Functional interactions of neurotrophins and neurotrophin receptors. Annu Rev Neurosci, in press.

Bothwell M, Kinoshita Y, Schober A, Borson S, von Bartheld CS (1993) Noradrenergic neurons in locus coeruleus: effects of neurotrophins in vitro and identification of targets in vivo. Soc Neurosci Abstr 19:1101.

Campenot RB (1982) Development of sympathetic neurons in com- partmentalized cultures. I. Local control of neurite growth by nerve growth factor. Dev Biol 93:1-12.

Chao MV (1992) Neurotrophin receptors: a window into neuronal differentiation. Neuron 9:583-593.

Cowan WM, Fawcett JW, O'Leary DD, Stanfield BB (1984) Regressive events in neurogenesis. Science 225:1258-1265.

Davies DC, Horn G, McCabe BJ (1983) Changes in telencephalic catecholamine levels in the domestic chick. Effects of age and visual experience. Dev Brain Res 10:251-255.

Davies DC, Horn G, McCabe BJ (1985) Noradrenaline and learning. the effects of the noradrenergic neurotoxin DSP4 on imprinting in the domestic chick. Behav Neurosci 100:51-56.

Dechant G, Rodriguez-Tebar A, Kolbeck R, Barde Y-A (1993) Specific high-affinity receptors for neurotrophin-3 on sympathetic neurons. J Neurosci 13:2610-2616.

Dreyfus CF, Peterson ER, Crain SM (1980) Failure of nerve growth factor to affect fetal mouse brain stem catecholaminergic neurons in culture. Brain Res 194:540-547.

Dubé L, Parent A (1981) The monoamine-containing neurons in avian brain. I. A study of the brainstem of the chicken (Gallus domesticus) by means of fluorescence and acelylcholinesterase histochenistry. J Comp Neurol 196:695-708.

Ebendal T (1992) Function and evolution in the NGF family and its receptors. J Neurosci Res 32:461-470.

Ebendal T, Larhammar D, Persson H (1986) Structure and expression of the chicken beta-nerve growth factor gene. EMBO J 5:1483-1487.

Foote SL, Bloom FE, Aston-Jones G (1983) Nucleus locus ceruleus: new evidence of anatomical and physiological specificity. Physiol Rev 63:844-914.

Freed WJ (1976) The role of nerve growth factor (NGF) in the central nervous system. Brain Res Bull 1:393 -412 .

Friedinan WJ, Ibanez CF, Hallböök F, Persson $\mathbf{H}$, Cain LD, Dreyfus CF, Black IB (1993) Differential actions of neurotrophins in the locus coeruleus and basal forebrain. Exp Neurol 119:72-78.

Frisén J, Verge VMK, Fried K, Risling M, Persson H, Trotter J, Hökfelt T, Lindholm D (1993) Characterization of glial trkB receptors: differential response to injury in the central and peripheral nervous systems. Proc Natl Acad Sci USA 90:4971-4975.

German DC, Manaye KF, White CL, Woodward DJ, McIntire DD, Smith WK, Kalaria RN, Maun DMA (1992) Disease-specific patterns of locus coeruleus cell loss. Ann Neurol 32:667-676.

Gordon B, Allen EE, Trombley PQ (1988) The role of norepinephrine in plasticity of the visual cortex. Prog Neurobiol 30:171-191.

Guglielmone R, Panzica GC (1982) Topographic, morphologic, and developmental characterization of the nucleus locus coerulei in the chicken. Cell Tissue Res 225:95-110.

Hamburger V, Hamilton $H$ (1951) A series of normal stages in the development of the chick embryo. J Morphol 88:49-92.

Hayashi M, Edgar D, Thoenen H (1985) Nerve growth factor changes the relative levels of neuropeptides in developing sensory and sympathetic ganglia of the chick embryo. Dev Biol 108:49 55

Hefti F (1986) Nerve growth factor promotes survival of septal cholinergic neurons after fimbrial transections. J Neurosci 6:2155-2162.

Hempstead BL, Martin-Zanca D, Kaplan DR, Parada LF, Chao MV (1991) High affinity NGF binding requires co-expression of the $t r k$ proto-oncogene and the low-affinity NGF receptor. Nature 350:678683.

Heuer JG, von Bartheld CS, Kinoshita Y, Evers PC, Bothwell M (1990) Alternating phases of FGF receptor and NGF receptor expression in the developing chicken nervous system. Neuron 5:283-296.

Hobson JA, Brazier MAB (1980) International Brain Research Organization monograph series, Vol 6 , The reticular formation revisited.

Holtzman DM, Kilbridge J, Li Y, Cunningham ET Jr, Lenn NJ, Clary DO, Reichardt LF, Mobley WC (1994) TrkA expression in the CNS: evidence for the existence of several novel NGF-responsive CNS neurons. J Neurosci, in press.

Johnson JE, Wang SW, Garner A, Baeshore K, Large T, McKay S, Oppenheim RW (1993) In situ hybridization of trkB in the developing chick visual system and brain. Soc Neurosci Abstr 19:1298.

Kety SS (1970) The hingenic amines in the central nervous system: their possible role in arousal, emotion and learning. In: The Neurosciences second study program (Schmitt FO, ed), pp 324-336. New York: Rockefeller UP.

Kitt CA, Brauth SE (1986) Telencephalic projections from midbrain 
and isthmal cell groups in the pigeon. I. locus coeruleus and subcoeruleus. J Comp Neurol 247:69-91.

Klein R, Nanduri V, Jing S, Lamballe F, Tapley P, Bryant S, CordonCardo C, Jones KR, Reichardt LF, Barbacid M (1991) The trkB tyrosine protein kinase is a receptor for brain-derived neurotrophic factor and neurotrophin-3. Cell 66:395-403.

Koh S, Oyler GA, Higgins GA (1989) Localization of nerve growth factor receptor messenger RNA and protein in the adult rat brain. Exp Neurol 106:209-221.

Konigsmark BW (1970) Methods for counting of neurons. In: Contemporary research methods in neuroanatomy (Nauta WJH, Ebbesson SOE, eds), pp 315-340. New York: Springer.

Konkol RJ, Mailman RB, Bendeich EG, Garrison AM, Mueller RA, Breese GR (1978) Evaluation of the effects of nerve growth factor and anti-nerve growth factor on the development of central catecholamine-containing neurons. Brain Res 144:277-285.

Korsching S, Thoenen H (1983) Nerve growth factor in sympathetic ganglia and corresponding target organs of the rat: correlation with density of sympathetic innervation. Proc Natl Acad Sci USA 80: 3513-3516.

Kuenzel WJ, Masson M (1988) $\Lambda$ stereotaxic atlas of the brain of the chick (Gallus domesticus). Baltimore: Johns Hopkins UP.

Landis SC (1988) Neurotransmitter plasticity in sympathetic neurons and its regulation of environmental factors in vitro and in vivo. In: Handbook of chemical neuroanatomy, Vol 6, The peripheral nervous system (Björklund A, Hökfelt T, Owman C, eds), pp 65-115. Amsterdam: Elsevier.

Landis SC (1990) Target regulation of neurotransmitter phenotype. Trends Neurosci 13:344-350.

Large TH, Weskamp G, Helder JC, Radeke MJ, Miskio TP, Shooter EM, Reichardt LF (1989) Structure and developmental expression of the nerve growth factor receptor in the chicken central nervous system. Neuron 2:1123-1134.

Lauder JM, Bloom FE (1974) Ontogeny of monoamine neurons in the locus coeruleus, Raphe nuclei and substantia nigra of the rat. I. cell differentiation. J Comp Neurol 155:469-481.

Levi-Montalcini R (1974) Control mechanisms of the adrenergic neuron. In: Dynamics of degeneration and growth in neurons (Fuxe $\mathrm{K}$, Olson L, Zotterman Y, eds), pp 297-314. Oxford: Pergamon.

Levi-Montalcini $\mathrm{R}$, Cohen $\mathrm{S}$ (1956) In vitro and in vivo effects of a nerve growth-stimulating agent isolated from snake venom. Proc Natl Acad Sci USA 42:695-699.

Levi-Montalcini R, Cohen S (1960) Effects of the extract of the mouse submaxillary salivary glands on the sympathetic system of mammals. Ann NY Acad Sci 85:324-341.

Levi-Montalcini R, Aloc L, Mugnaini E, Oesch F, Thoenen H (1975) Nerve growth factor induces volume increases and enhances tyrosine hydroxylase synthesis in chemically axotomized sympathetic ganglia of newborn rats. Proc Natl Acad Sci USA 72:595-599.

Lindsay RM (1979) Adult rat brain astrocytes support survival of both NGF-dependent and NGF-insensitive neurones. Nature 282:80-82.

Lindsay RM, Harmar AJ (1989) Nerve growth factor regulates expression of neuropeptide genes in adult sensory neurons. Nature 337: 362-364.

Loughlin SE, Foote SL, Bloom FE (1986a) Efferent projections of nucleus locus coeruleus: topographic organization of cells of origin demonstrated by the three-dimensional reconstruction. Neuroscience 18:291-306.

Loughlin SE, Foote SL, Grzanna R (1986b) Efferent projections of nucleus locus coeruleus: inorphologic subpopulations have different efferent targets. Neuroscience 18:307-319.

Lu B, Yokoyama M, Dreyfus CF, Black IB (1991) NGF gene expression in actively growing brain glia. J Neurosci 11:318-326.

Mason ST (1984) Catecholamines and behaviour. Cambridge: Cambridge UP

Masuko S, Nakajima Y, Nakajima S, Yamaguchi K (1986) Noradrenergic neurons from the locus ceruleus in dissociated cell culture: culture methods, morphology and electrophysiology. J Neurosci 6:3229_ 3241 .

Meakin SO, Shooter EM (1992) The nerve growth factor family of receptors. Trends Neurosci 15:323-331.

Merlio J-P, Ernfors P, Jaber M, Persson H (1992) Molecular cloning of rat trkC and distribution of cells expressing messenger RNAs for members of the trk family in the rat central nervous system. Neuroscience 51:513-532.
Mesulam M-M, Geula C, Bothwell MA, Hersh LB (1989) Human reticular formation: cholinergic neurons of the pedunculopontine and laterodorsal tegmental nuclei and some cytochemical comparisons to forebrain cholinergic neurons. I Comp Neurol 283:611-633.

Mobley WC, Schenke A, Shooter EM (1976) Characterization and isolation of proteolytically modified nerve growth factor. Biochemistry 15:5543-5552.

Moore RY, Bloom FE (1979) Central catecholamine neuron systems: anatomy and physiology of the norepinephrine and epinephrine systems. Annu Rev Neurosci 2:113-168.

Mugnaini E, Dahl A-L (1975) Mode of distribution of aminergic fibers in the cerebellar cortex of the chicken. J Comp Neurol 162:417-432.

Nakamura S, Sakaguchi T (1990) Development and plasticity of the locus coeruleus: a review of recent physiological and pharmacological experimentation. Prog Neurobiol 34:505-526.

Olson L (1993) NGF and the treatment of Alzheimer's disease. Exp Neurol 124:5-15.

Olson L, Ebendal T, Seiger A (1979) NGF and anti-NGF: evidence against effects on fiber growth in locus coeruleus from cultures of perinatal CNS tissues. Dev Neurosci 2:160-176.

Oppenheim RW, Prevette D, Qin-Wei Y, Collins F, MacDonald J (1991) Control of embryonic motoneuron survival in vivo by ciliary neurotrophic factor. Science 251:1616-1618.

Parent A, Poitras D, Dubé L (1984) Comparative anatomy of central monoaminergic systems. In: Handbook of chemical neuroanatomy, Vol 2, Classical transmitters in the CNS, Pt I (Björklund A, Hökfelt T, eds), pp 409-439. Amsterdam: Elsevier.

Patterson SP, Grover LM, Schwartzkroin PA, Bothwell M (1992) Neurotrophin expression in rat hippocampal slices: a stimulus paradigm inducing LTP in CA1 evokes increases in BDNF and NT-3 mRNAs. Neuron 9:1081-1088.

Pioro EP, Cuello AC (1990) Distribution of nerve growth factor-like immunoreactivity in the adult rat central nervous system. Effect of colchicine and correlation with the cholinergic system. II. Brainstem, cerebellum and spinal cord. Neuroscience 34:89-110.

Purves D (1988) Body and brain. A trophic theory of neural connections. Cambridge, MA: Harvard UP.

Raivich G, Zimmermann A, Sutter A (1987) Nerve growth factor (NGF) receptor expression in chicken cranial development. J Comp Neurol 256:229-245.

Ramon-Moliner E, Nauta WJH (1966) The isodendritic core of the brain stem. J Comp Neurol 126:311-336.

Rodman HR, Karten HJ (1991) Laminar distribution and origins of the catecholaminergic innervation of the optic tectum in the pigeon ( $\mathrm{Co}$ lumba livia). Soc Neurosci Abstr 17:112.

Saper CB, Wainer BH, German DC (1987) Axonal and transneuronal transport in the transmission of neurological disease: potential role in system degenerations, including Alzheimer's disease. Neuroscience 23:389-398.

Schwab ME, Otten U, Agid Y, Thoenen H (1979) Nerve growth factor (NGF) in the rat CNS: absence of specific retrograde axonal transport and tyrosine hydroxylase induction in locus coeruleus and substantia nigra. Brain Res 168:473-483.

Singer HS, Coyle JT, Vernon N, Kallman CH, Price DL (1980) The development of catecholaminergic innervation in chick spinal cord. Brain Res 191:417-428.

Smeyne RJ, Klein R, Schnapp A, Long LK, Bryant S, Lewin A, Lira SA, Barbacid M (1994) Severe sensory and sympathetic neuropathies in mice carrying a disrupted Trk/NGF receptor gene. Nature 368:246-249.

Stenevi U, Björklund A, Moore RY (1973) Morphological plasticity of central adrenergic neurons. Brain Behav Evol 8:110-134.

Stenevi U, Bjerre B, Björklund A, Mobley W (1974) Effects of localized intracerebral injections of nerve growth factor on the regenerative growth of lesioned central noradrenergic neurons. Brain Res 69: 217-234.

Stephenson RM (1991) Monoamine systems and memory formation. In: Neural and behavioral plasticity. The use of the domestic chick as a model (Andrew RJ, ed), pp 419-439. London: Oxford UP.

Sutter A, Riopelle RJ, Harris-Warrick RM, Shooter EM (1979) Nerve growth factor receptors. J Biol Chem 254:5972-5982.

Tanaka H, Agata A, Obata K (1989) A new membrane antigen revealed by monoclonal antibodies is associated with motoneuron axonal pathways. Dev Biol 132:419-435. 
Thoenen $\mathrm{H}$ (1991) The changing scene of neurotrophic factors. Trends Neurosci 14:165-170.

Thoenen H, Angeletti PU, Levi-Montalcini R, Kettler R (1971) Selective induction by nerve growth factor of tyrosine hydroxylase and dopamine-beta-hydroxylase in the rat superior cervical ganglion. Proc Natl Acad Sci USA 68:1598-1602.

Thoenen H, Bandtlow C, Heumann R (1987) The physiological function of nerve growth factor in the central nervous system. Rev Physiol Biochem Pharmacol 109:145-178.

Tohyama M, Maeda T, Hashimoto J, RataShresta G, Tanura O, Shimuzu N (1974) Comparative anatomy of the locus ceruleus. I. Organization and ascending projections of catecholamine containing neurons in the pontine region of the bird, Melopsittacus undulatus. J Hirnforsch 15:319-330.

Towle AC, Lauder JM, Joh TH (1984) Optimization of tyrosine hydroxylase immunocytochemistry in paraffin sections using pretreatment with proteolytic enzymes. J Histochem Cytochem 32:766-770.

Ungerstedt U (1971) Histochemical studies on the effect of intracerebral and intraventricular injections of 6-hydroxydopamine on monoamine neurons in the rat brain. In: 6-Hydroxydopamine and catecholamine neurons (Malmfors T, Thoenen H, eds), pp 101-127. $\Lambda \mathrm{m}$ sterdam: North Holland.

von Bartheld CS, Bothwell M (1992) Development and distribution of noradrenergic and cholinergic neurons and their trophic phenotypes in the avian ceruleus complex and midbrain tegmentum. J Comp Neurol 320:479-500.

von Bartheld CS, Cunningham DE, Rubel EW (1990) Neuronal tracing with Dil: decalcification, cryosectioning, and photoconversion for light and electron microscopic analysis. J Histochem Cytochem 38: 725-733.

von Bartheld CS, Heuer JG, Bothwell M (1991a) Expression of nerve growth factor (NGF) receptors in the brain and retina of chick em bryos: comparison with cholinergic development. J Comp Neurol 310:103-129.

von Bartheld CS, Patterson SL, Heuer JG, Wheeler EF, Bothwell M,
Rubel EW (1991b) Expression of nerve growth factor (NGF) receptors in the developing inner ear of chick and rat. Development 113 . $455-470$.

von Bartheld CS, Schecterson LC, Bothwell M (1993) Retrograde and anterograde transport of neurotrophins from the eye to the brain in chick embryos. Soc Neurosci Abstr 19:1101.

von Bartheld CS, Kinoshita Y, Prevette D, Quin-Wei Y, Oppenheim RW, Bothwell M (1994a) Positive and negative effects of neurotrophins on the isthmo-optic nucleus in chick embryos. Neuron 12:639-654.

von Bartheld CS, Schober A, Kinoshita Y, Williams R, Bothwell M (1994b) Noradrenergic neurons in locus coeruleus of birds express p75 and trkA and respond to NGF. Soc Neurosci Abstr, in press.

Whittemore SR, Seiger A (1987) The expression, localization and functional significance of beta-nerve growth factor in the central nervous system. Brain Res Rev 12:439-464.

WillaıIss R, Bäckström A, Ebendal T, böök F (1993) Molecular cloning and cellular localization of trkC in the chicken embryo. Dev Brain Res 75:235-252.

Willams R, Bäckström A, Kullander K, Hallböök F, Ebendal T (1994) Developmentally-regulated expression of mRNA for neurotrophin high-affinity (trk) receptor within chick trigeminal neurons. Eur J Neurosci, in press.

Yan Q, Elliott JL, Matheson C, Sun J, Zhang L, Mu X, Rex KL, Snider WD (1993) Influences of neurotrophins on mammalian motoneurons in vivo. J Neurobiol 24:1555-1577.

Yurkewicz L, Lauder JM, Marchi M, Giacobini E (1981a) ${ }^{3} \mathrm{H}$ thymidine long survival autoradiography as a method for dating the time of neuronal origin in the chick embryo: the locus coeruleus and cerebellar Purkinje cells. J Comp Neurol 203:257-267.

Yurkewicz L, Marchi M, Lauder JM, Giacobini E (1981b) Development and aging of noradrenergic cell bodies and axon terminals in the chicken. J Neurosci Res 6:621-641.

Zafra F, Hengerer B, Leibrock J, Thoenen H, Lindholm D (1990) Activity-dependent regulation of BDNF and NGF mRNAs in the rat hippocampus is mediated by non-NMDA glutamate receptors. EMBO J 9:3545-3550. 